\title{
A Review on the Contemporary Development of Composite Materials Comprising Graphene/Graphene Derivatives
}

\author{
Fenfen Li, ${ }^{1}$ Linyu Long, ${ }^{1}$ and Yunxuan Weng $\mathbb{D}^{1,2}$ \\ ${ }^{1}$ School of Materials and Mechanical Engineering, Beijing Technology and Business University, Beijing 100048, China \\ ${ }^{2}$ Beijing Key Laboratory of Quality Evaluation Technology for Hygiene and Safety of Plastics, \\ Beijing Technology and Business University, Beijing 100048, China \\ Correspondence should be addressed to Yunxuan Weng; wyxuan@th.btbu.edu.cn
}

Received 26 June 2019; Accepted 16 January 2020; Published 12 February 2020

Academic Editor: Saliha Ilican

Copyright (C) 2020 Fenfen Li et al. This is an open access article distributed under the Creative Commons Attribution License, which permits unrestricted use, distribution, and reproduction in any medium, provided the original work is properly cited.

\begin{abstract}
As two-dimensional materials with a high specific surface area, strength, and electrical and thermal conductivity, graphene (Gr) and its derivatives have great application prospects in various fields such as structural reinforcement, energy storage, optics, and electrical and thermal conductivity. However, the current preparation method of $\mathrm{Gr}$ is complicated and expensive. Its preparation cost can be reduced using $\mathrm{Gr}$ composites that include inorganic materials or other polymers. Composite materials comprising $\mathrm{Gr}$ and inorganic materials are generally prepared using sinter molding, chemical reduction, or chemical deposition. Gr should be able to mitigate several of the defects resulting from inorganic materials, including their poor toughness, small specific capacity, and low photoelectric conversion rate. The mitigation of these defects should result in the expansion of the applications of Gr composites for use in capacitors, catalysts, and sensors, among other devices. Although solution blending or in situ polymerization produces a relatively good mixing effect, in general, melt blending is used in the large-scale processing of Gr composites with polymer materials. Gr can be used to partially mitigate several weaknesses of polymer materials, including their low strength, poor electrical and thermal conductivities, and poor isolation performance, and expand the applications of Gr composites for use in electrical and thermal conductive materials and functional membrane materials, among other applications. The goal of the present paper is to introduce the structural properties of $\mathrm{Gr}$ and a surface modification method for Gr. In addition, the preparation methods and application fields of different Gr composite materials are reviewed. Finally, the development prospects and key issues are discussed.
\end{abstract}

\section{Introduction}

In the 1950s, Wallace [1] proposed the concept of graphene (Gr) and theoretically explored the electronic structure of Gr. In 2004, the physicists Novoselov et al. [2] successfully separated $\mathrm{Gr}$ from graphite at the University of Manchester. Because of its unique two-dimensional planar structure and other advantages, including its high strength and electrical and thermal conductivities [3-7], Gr has attracted the interest of both researchers and commercial enterprises. However, the current preparation method for Gr is relatively complicated and expensive. Additionally, the difficulty of the molding process alone limits its applications. For use in practical applications, $\mathrm{Gr}$ and its derivatives are often composited with inorganic materials and polymers to prepare composite materials. The prepared composite materials have excellent properties, are of low cost, and have great application prospects for use in many fields, including structural reinforcement, energy storage, optics, conductive heat conduction, and biomaterials [8-12].

In recent years, there have been many research literatures on $\mathrm{Gr}$ composites, but the quantity of review literature is limited. For researchers who want to study $\mathrm{Gr}$ composites for the first time, it is difficult to have a comprehensive understanding. Some of literature on Gr composites describes the research status based on different application fields, and the content covered limited types of materials. It is difficult for researchers to see the preparation methods and possible application fields of a certain material. In this review, the research progress of $\mathrm{Gr}$ composites is 
summarized from the perspectives of Gr/inorganic and $\mathrm{Gr}$ / polymer composites. The preparation methods and properties of different materials are described based on the matrix types of composite materials. It may have some guiding significance for the researcher to choose the matrix material and preparation method when preparing Gr composite materials with certain properties.

This review, which encompasses the data from 144 papers, discusses the structural properties and applied surface functionalization methods of Gr. The methods used for the preparation of $\mathrm{Gr} /$ inorganics and $\mathrm{Gr} /$ polymer composite materials and their possible applications are summarized herein. In addition, this paper discusses the developmental prospects of Gr composites and their key technical issues.

\section{Graphene}

2.1. Introduction to Graphene. $\mathrm{Gr}$ is a two-dimensional crystal material composed of layers of carbon atoms [13]. Its unique structure provides its remarkable performance for various applications. Its large specific surface area, excellent electrical performance, very small resistivity, and very high thermal conductivity are properties that stem from its unique structure [14-16]. At present, the primary synthetic methods used for Gr synthesis include chemical gas deposition (CVD), epitaxial growth, mechanical exfoliation, and oxidation-reduction; the oxidation-reduction method has been used in the widest range of applications [17-21].

2.2. Functionalization of Graphene. In the preparation of composite materials, the functionalization of $\mathrm{Gr}$ is necessary because the neat structure of $\mathrm{Gr}$ has weak interactions with other materials, which results in its poor dispersion.

The backbone of $\mathrm{Gr}$ consists of a stable multiring aromatic hydrocarbon chain; its edges and defects have the highest reaction activity [22]. The surfaces of Gr derivatives, such as graphene oxide (GO), contain a large amount of oxygen-containing functional groups, which can react with other functional groups and form chemical bonds $[23,24]$. The functionalization of $\mathrm{Gr}$ can be divided into the following two categories: non-covalent and covalent functionalization [25, 26] (Figure 1).

Surface functional modification using noncovalent bonds primarily involves the formation of bonds between chemical substances and the Gr surface via intermolecular forces $[27,28]$, which has the advantage of maintaining the bulk structure and desirable properties of Gr or GO without destroying either its bulk structure or properties. Simultaneously, surface functional modification using non-covalent bonds can be used to improve the dispersibility of Gr, but the resulting graphene composite is unstable and its intermolecular forces are weak. Comparatively, covalent bond functional modification is achieved by introducing a functional group capable of forming a covalent bond with reactive double bonds or another oxygen-containing group on the Gr or GO surface $[29,30]$. Compared with non-covalent bond functionalization, covalent bond functionalization is more stable but affects performance because it destroys the structure of Gr.

\section{Graphene Composite Materials}

Figure 2 shows the primary preparation methods and applications of $\mathrm{Gr}$ composite materials.

Figure 2 shows $\mathrm{Gr}$ is a high-strength, two-dimensional material with high electrical and thermal conductivities. After being composited with inorganic materials or polymers, Gr composites are generally classified into the following two categories: Gr/inorganic and Gr/polymer composite materials [31, 32]. Composite materials have been widely used in photoelectric conversion materials, catalysts, structure-reinforcing materials, adhesives, functional film materials, and biomedical materials, among others.

\subsection{Graphene/Inorganic Composite Materials}

\subsubsection{Preparation of Graphene/Inorganic Composite} Materials. Gr/organic composite materials primarily include $\mathrm{Gr} / \mathrm{metal}$ composite materials, Gr/ceramic composite materials, and Gr/other inorganic composite materials. Selection of the preparation method is dependent on the properties of inorganic materials and the application of the composite materials involved. The primary methods used for preparation include sinter molding, hydrothermal, electrochemical deposition, chemical reduction, and sol-gel methods, among others. Specific advantages/disadvantages and the application ranges of these methods are listed in Table 1.

\subsubsection{Applications of Graphene/Inorganic Composite} Materials

\section{(1) Graphene/Metal Composite Materials}

(i) Graphene/metal elements

Table 2 provides a summary of the properties and preparation methods of $\mathrm{Gr} /$ metal composite materials.

Because of its highly desirable mechanical properties, Gr has demonstrated significant potential in the reinforcement of metallic materials. Table 2 shows the composite materials comprising $\mathrm{Gr}$ and elemental metallic materials have primarily been used for increasing the mechanical strength of materials. Tensile strength increased by over $50 \%$ after $\mathrm{Gr}$ or RGO was added to metallic elements such as $\mathrm{Al}$ and $\mathrm{Cu}$ [37-41]. For example, $\mathrm{Gr}-\mathrm{Cu} / \mathrm{Al}$ prepared by Zhao showed a $77.5 \%$ increase in tensile strength over that of pure $\mathrm{Cu}$.

Gr is able to enhance the thermal conductivity of metal materials because its thermal conductivity is higher than that of most metallic materials. Rho prepared a graphene/Cu composite material with a 


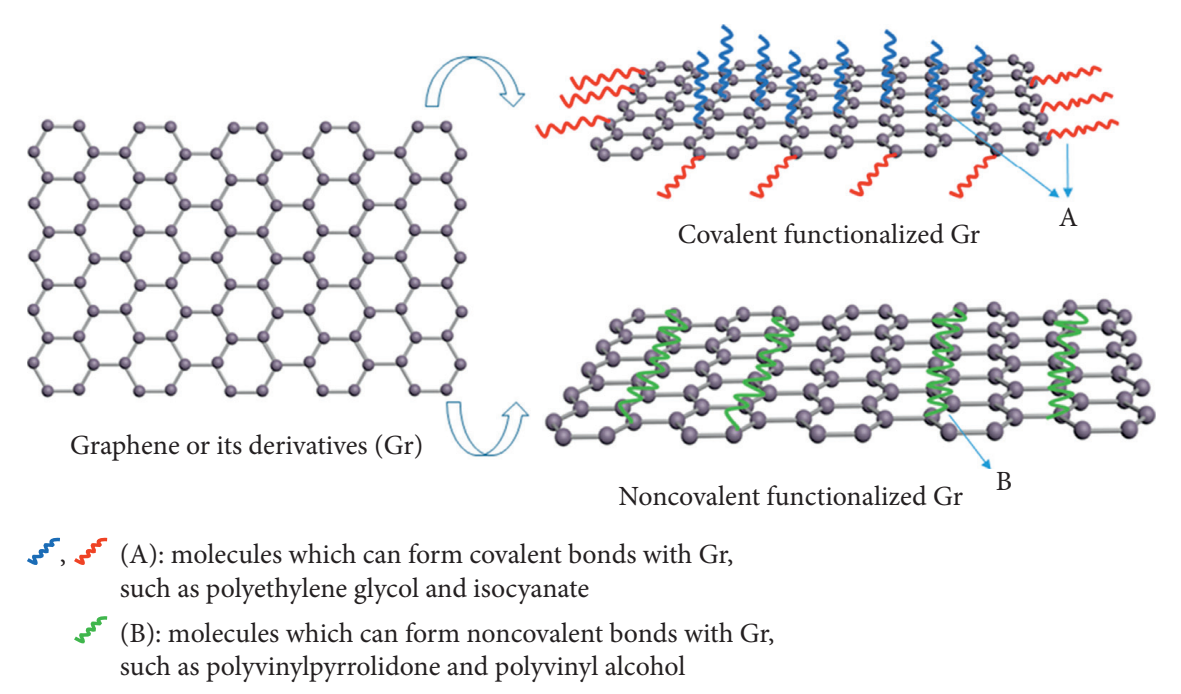

FIgURE 1: Covalent and noncovalent functionalization of graphene and its derivatives.

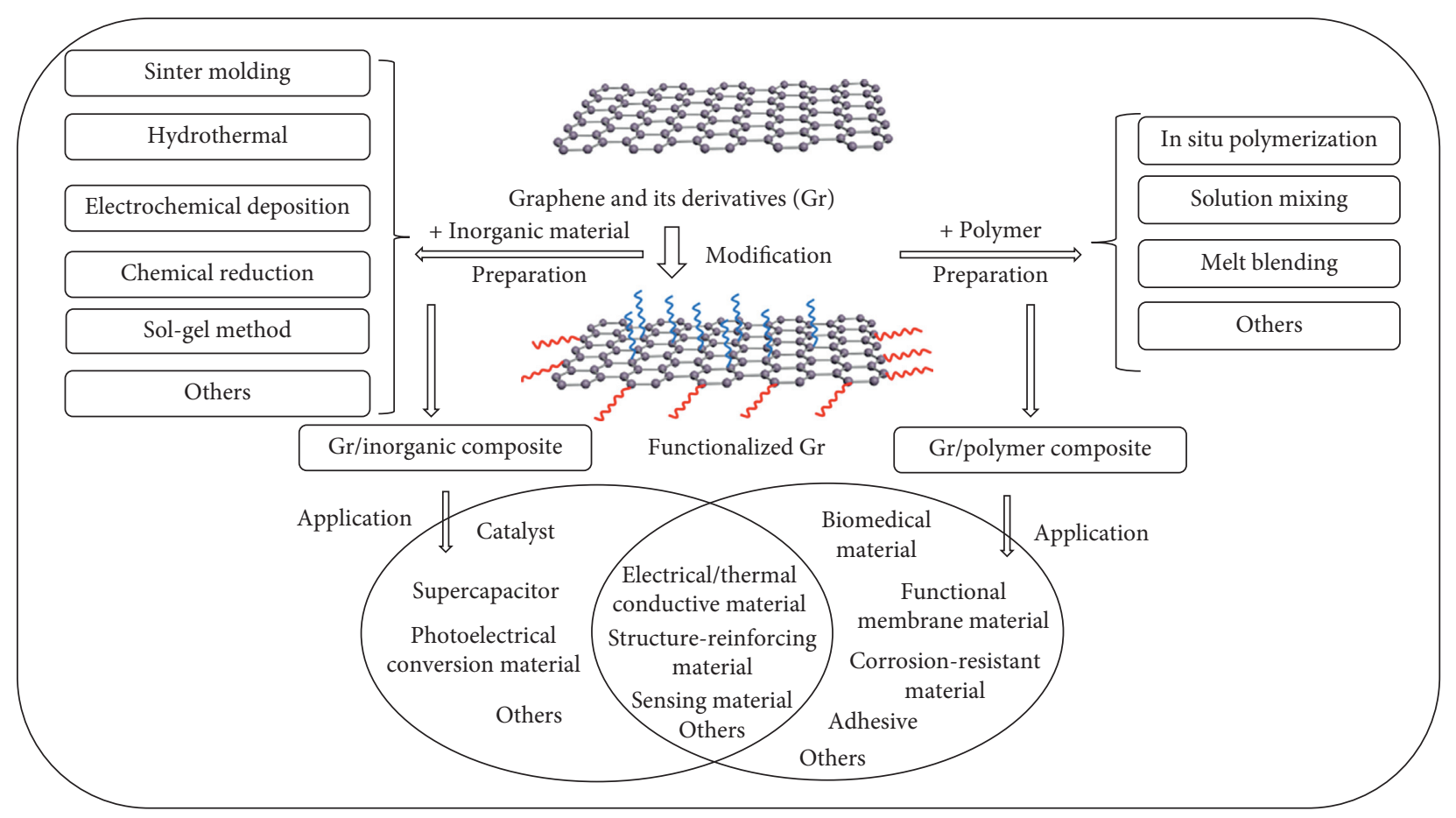

FIgURE 2: Preparation and application of graphene composite materials.

porosity of $35 \%$, which exhibited a thermal conductivity $40 \%$ higher than that of pure $\mathrm{Cu}$.

Because of its large specific surface area, Gr can be used to increase the sensitivity of composite materials used in sensors. The addition of Gr to catalyst carriers enlarges the contact area between reagents and significantly enhances catalytic performance. Sensors using certain metal elements (e.g., Pt and Ag) as a matrix can be quite sensitive, and the addition of these metal elements can significantly increase catalysis efficiency [44-47]. Ouyang used Gr to coat a flexible Ag membrane sensor, which was used to detect malachite green with high sensitivity. (ii) Graphene/metal oxide

Table 3 provides a summary of the properties and preparation methods of $\mathrm{Gr} /$ metal oxide composite materials.

Table 3 shows supercapacitors with excellent performance can be prepared using $\mathrm{Gr} /$ metal oxide composites. The specific capacities of the obtained capacitors were higher than those comprising metal oxides containing no $\mathrm{Gr}$, and the cycle stability was good [49-56]. Of particular interest, one study by Liu et al. described the preparation of $\mathrm{RGO} / \mathrm{V}_{2} \mathrm{O}_{5}$ composite material, which exhibited a capacitance of 
TABle 1: Preparation methods, advantages, disadvantages, and the scope of application of graphene/inorganic composite materials [33-36].

\begin{tabular}{|c|c|c|c|}
\hline $\begin{array}{l}\text { Preparation } \\
\text { method }\end{array}$ & Advantages & Disadvantages & Scope of applications \\
\hline Sinter molding & $\begin{array}{l}\text { Simple fabrication process; shape of } \\
\text { fabricated product close to the final } \\
\text { shape of product needed; option of } \\
\text { pressureless sintering for products } \\
\text { with complex shapes; option of using } \\
\text { hot-pressed or spark plasma } \\
\text { sintering, which provide excellent } \\
\text { properties }\end{array}$ & $\begin{array}{l}\text { Limited variation in shape when using } \\
\text { a single mold, high energy } \\
\text { consumption at high temperatures, } \\
\text { low production efficiency }\end{array}$ & $\begin{array}{c}\text { Metallic powders or mixtures of } \\
\text { metals and nonmetals primarily used } \\
\text { in the fabrication of alloy, ceramic, } \\
\text { and composite materials }\end{array}$ \\
\hline Hydrothermal & $\begin{array}{l}\text { Fabrication of materials with high } \\
\text { purity, good dispersion of Gr in } \\
\text { matrices, good and controllable grain } \\
\text { shape, low production cost }\end{array}$ & $\begin{array}{l}\text { High equipment requirement, } \\
\text { relatively difficult technique, presence } \\
\text { of various influencing factors during } \\
\text { preparation }\end{array}$ & $\begin{array}{l}\text { Metal or metal oxide composite } \\
\text { materials usually used in the } \\
\text { fabrication of electronic materials, } \\
\text { magnetic materials, and sensor } \\
\text { matrices }\end{array}$ \\
\hline $\begin{array}{l}\text { Electrochemical } \\
\text { deposition }\end{array}$ & $\begin{array}{l}\text { Uniform distribution of } \mathrm{Gr}, \\
\text { fabrication of a more complete } \\
\text { structure, ability to obtain a } \\
\text { composite material with uniform } \\
\text { properties }\end{array}$ & $\begin{array}{c}\text { Production of a thin coating of } \\
\text { composite material, fabrication of a } \\
\text { composite with low mechanical } \\
\text { strength }\end{array}$ & $\begin{array}{l}\text { Facile precipitation of metals and } \\
\text { alloys from solution, which is } \\
\text { primarily used in the production of } \\
\text { metallic films }\end{array}$ \\
\hline $\begin{array}{l}\text { Chemical } \\
\text { reduction }\end{array}$ & $\begin{array}{l}\text { Simple and low-cost process } \\
\text { resulting in a material with good } \\
\text { performance }\end{array}$ & $\begin{array}{c}\text { Possibility that reducing agent may be } \\
\text { hazardous and dangerous }\end{array}$ & Metal-based Gr composite materials \\
\hline Sol-gel & $\begin{array}{l}\text { Easily controllable process, facile } \\
\text { reaction, ability of Gr to mix } \\
\text { uniformly with matrices at the } \\
\text { molecular scale }\end{array}$ & $\begin{array}{l}\text { Low production efficiency; occurrence } \\
\text { of micropores in composite materials; } \\
\text { easy occurrence of shrinkage, which } \\
\text { affects product shape }\end{array}$ & $\begin{array}{c}\text { Structural and film materials with } \\
\text { metal oxide/Gr composite materials, } \\
\text { use of composite materials as } \\
\text { insulating materials }\end{array}$ \\
\hline
\end{tabular}

TABLE 2: Properties and preparation methods of graphene/metal composite materials.

\begin{tabular}{|c|c|c|c|c|c|}
\hline Properties & Type & Preparation method & Loading & Result(s) after addition of graphene & Reference \\
\hline \multirow{5}{*}{ Mechanical } & $\begin{array}{l}\text { Reduced graphene oxide } \\
\text { (RGO)/Cu }\end{array}$ & $\begin{array}{l}\text { Electrochemical } \\
\text { deposition }\end{array}$ & 2.5 vol. $\%$ & $\begin{array}{c}\text { Elastic modulus and yielding strength were } \\
1.3 \text { and } 1.8 \text { folds, respectively, higher than } \\
\text { those of pure } \mathrm{Cu}\end{array}$ & {$[37]$} \\
\hline & $\mathrm{Gr} / \mathrm{Cu}$ & Sintering & 0.5 wt. $\%$ & $\begin{array}{l}\text { Yielding strength and tensile strength were } \\
233.3 \% \text { and } 35.7 \% \text {, respectively, higher } \\
\text { than those of pure Cu }\end{array}$ & {$[38]$} \\
\hline & Gr nanosheets (GNS)/Cu & Sintering & 3.0 wt.\% & $\begin{array}{c}\text { Tensile strength was } 69 \% \text { higher than that } \\
\text { of pure } \mathrm{Cu}\end{array}$ & {$[39]$} \\
\hline & $\mathrm{Gr}-\mathrm{Cu} / \mathrm{Al}$ & Sintering & 3.0 wt.\% & $\begin{array}{c}\text { Tensile strength and hardness were } 77.5 \% \\
\text { and } 29.1 \% \text {, respectively, higher than those } \\
\text { of pure } \mathrm{Al}\end{array}$ & {$[40]$} \\
\hline & $\mathrm{Gr} / \mathrm{Al}$ & Sintering & 1.0 wt.\% & $\begin{array}{c}\text { Bending strength was } 47 \% \text { higher than that } \\
\text { of } 6061 \mathrm{Al} \text { matrix }\end{array}$ & {$[41]$} \\
\hline \multirow{2}{*}{ Thermal } & $\mathrm{Gr} / \mathrm{Cu}$ & Sintering & - & $\begin{array}{c}\text { Thermal conductivity was } 40 \% \text { higher than } \\
\text { that of pure } \mathrm{Cu}\end{array}$ & {$[42]$} \\
\hline & $\mathrm{Gr} / \mathrm{Cu}$ & $\begin{array}{c}\text { Electrochemical } \\
\text { deposition }\end{array}$ & - & $\begin{array}{c}\text { Thermal conductivity was } 24 \% \text { higher than } \\
\text { that of pure } \mathrm{Cu}\end{array}$ & {$[43]$} \\
\hline \multirow{2}{*}{ Sensing } & $\mathrm{Gr} / \mathrm{Ag}$ & $\begin{array}{l}\text { Electrochemical } \\
\text { deposition }\end{array}$ & - & $\begin{array}{l}\text { Concentration of antibiotics in water was } \\
\text { determined successfully }\end{array}$ & {$[44]$} \\
\hline & $\mathrm{Gr} / \mathrm{Ag}$ & Chemical reduction & - & $\begin{array}{l}\text { Precise detection of malachite green was } \\
\text { achieved successfully }\end{array}$ & {$[45]$} \\
\hline \multirow{2}{*}{ Catalytic } & $\mathrm{RGO} / \mathrm{Pt}$ & Chemical reduction & - & $\begin{array}{l}\text { Catalytic efficiency of fuel batteries was } \\
\text { enhanced successfully }\end{array}$ & {$[46]$} \\
\hline & $\begin{array}{l}\text { Graphene nanospheres } \\
\text { (GNs)/Pt }\end{array}$ & Chemical reduction & - & $\begin{array}{l}\text { Catalytic efficiency of hydrogen evolution } \\
\text { reaction was enhanced successfully }\end{array}$ & {$[47]$} \\
\hline Antibacterial & $\mathrm{RGO} / \mathrm{Ag}$ & Chemical reduction & - & $\begin{array}{l}\text { Use as an antibacterial and photothermal } \\
\text { ablation agent was demonstrated }\end{array}$ & {$[48]$} \\
\hline
\end{tabular}


TABLE 3: Properties and preparation methods of graphene/metal oxide composite materials.

\begin{tabular}{|c|c|c|c|c|}
\hline Properties & Type & Preparation method & Result(s) after addition of $\mathrm{Gr}$ & Reference \\
\hline \multirow{8}{*}{ Electrical } & $\mathrm{GO} / \mathrm{CuO}$ & $\begin{array}{l}\text { Electrochemical } \\
\text { deposition }\end{array}$ & Specific capacity was enhanced by $72 \%$ & [49] \\
\hline & $\mathrm{Gr} / \mathrm{SnO}_{2}$ & Chemical reduction & Excellent cycling stability was achieved & {$[50]$} \\
\hline & $\mathrm{RGO} / \mathrm{V}_{2} \mathrm{O}_{5}$ & $\begin{array}{l}\text { Hydrothermal } \\
\text { method }\end{array}$ & Specific capacitance was $384 \mathrm{~F} / \mathrm{g}$ at $0.1 \mathrm{~A} / \mathrm{g}$ & {$[51]$} \\
\hline & $\mathrm{RGO} / \mathrm{V}_{2} \mathrm{O}_{5}$ & $\begin{array}{l}\text { Hydrothermal } \\
\text { method }\end{array}$ & Capacitance retention was nearly $81.5 \%$ after 200 cycles & {$[52]$} \\
\hline & $\mathrm{RGO} / \mathrm{V}_{2} \mathrm{O}_{5}$ & $\begin{array}{l}\text { Hydrothermal } \\
\text { method }\end{array}$ & $\begin{array}{l}\text { Specific capacitance was } 450.5 \mathrm{~F} / \mathrm{g} \text { at } 0.5 \mathrm{~A} / \mathrm{g} \text {; capacitance retention } \\
\text { was nearly } 73.3 \% \text { at } 10 \mathrm{~A} / \mathrm{g}\end{array}$ & [53] \\
\hline & $\begin{array}{l}\text { Microwave-exfoliated } \\
\text { graphene oxide } \\
(\mathrm{MEGO}) / \mathrm{MnO}_{2}\end{array}$ & Chemical reduction & $\begin{array}{c}\text { Mass specific capacitance and volumetric specific capacitance } \\
\text { achieved values of } 256 \mathrm{~F} / \mathrm{g} \text { and } 640 \mathrm{~F} / \mathrm{cm}^{3}\end{array}$ & {$[54]$} \\
\hline & $\mathrm{Gr} / \mathrm{MnO}-\mathrm{NiO}$ & Interface method & Specific capacity was $813 \mathrm{~F} / \mathrm{g}$ at $0.5 \mathrm{~A} / \mathrm{g}$ & [55] \\
\hline & $\mathrm{GrF} / \mathrm{Co}_{3} \mathrm{O}_{4}$ & In situ growth & Specific capacity was $277.5 \mathrm{~F} / \mathrm{g}$ at $25 \mathrm{~A} / \mathrm{g}$ & {$[56]$} \\
\hline \multirow{5}{*}{ Catalytic } & $\mathrm{Gr} / \mathrm{SnO}_{2}$ & $\begin{array}{l}\text { Hydrothermal } \\
\text { method }\end{array}$ & $\begin{array}{l}\text { Higher photocatalytic activity was achieved, resulting in the } \\
\text { elimination of } 93 \% \text { of rhodamine B }\end{array}$ & {$[57]$} \\
\hline & $\mathrm{Gr} / \mathrm{MnO}_{2}$ & $\begin{array}{l}\text { Hydrothermal } \\
\text { method }\end{array}$ & Methanal conversion was $80 \%$ higher than that of $\mathrm{MnO}_{2}$ & {$[58]$} \\
\hline & $\mathrm{Gr} / \mathrm{TiO}_{2}$ & $\begin{array}{l}\text { Hydrothermal } \\
\text { method }\end{array}$ & $\begin{array}{l}\text { Degradation of methylene blue was more efficient than that of pure } \\
\qquad \mathrm{TiO}_{2}\end{array}$ & [59] \\
\hline & $\mathrm{RGO} / \mathrm{V}_{2} \mathrm{O}_{5}$ & $\begin{array}{l}\text { Hydrothermal } \\
\text { method }\end{array}$ & $\begin{array}{c}\text { Maximum photocatalytic degradation was achieved, and discolor } \\
\text { efficiency for methylene blue was } 85 \%\end{array}$ & {$[60]$} \\
\hline & $\mathrm{Gr} / \mathrm{TiO}_{2}$ & $\begin{array}{l}\text { Hydrothermal } \\
\text { method }\end{array}$ & $\begin{array}{l}\text { Excellent adsorption performance and catalytic capability under } \\
\text { visible light were achieved; the removal rate of methylene blue was } \\
\text { over } 90 \%\end{array}$ & {$[61]$} \\
\hline \multirow{3}{*}{ Sensing } & $\mathrm{RGO} / \mathrm{CuO}$ & $\begin{array}{l}\text { Electrochemical } \\
\text { deposition }\end{array}$ & Detection of low concentrations of $\mathrm{NO}_{2}(1-75 \mathrm{ppm})$ was achieved & {$[62]$} \\
\hline & $\mathrm{RGO} / \mathrm{SnO}_{2}$ & Drop casting & $\begin{array}{l}\text { Simultaneous detection of } \mathrm{H}_{2} \mathrm{~S} \text { and acetone was achieved; this } \\
\text { method can be used to diagnose human diabetes using a } \\
\text { noncontact technique }\end{array}$ & {$[63]$} \\
\hline & $\begin{array}{l}\mathrm{SnO}_{2} @ \mathrm{RGO}-\text { poly } \\
\text { aniline (PANI) }\end{array}$ & $\begin{array}{l}\text { In situ } \\
\text { polymerization }\end{array}$ & $\begin{array}{c}\text { Room-temperature response to } 100-10000 \mathrm{ppm} \text { methane was } \\
\text { intensified }\end{array}$ & {$[64]$} \\
\hline
\end{tabular}

$450.5 \mathrm{~F} / \mathrm{g}$ at $0.5 \mathrm{~A} / \mathrm{g}$ and a capacitance retention of $81.5 \%$ at $10 \mathrm{~A} / \mathrm{g}$.

The photothermal effect of Gr can enhance the catalytic efficiency of traditional thermal catalysts. Table 3 shows $\mathrm{Gr}$ and metal oxides are excellent materials for use in the photocatalytic degradation of dye [57-61]. For example, the photocatalytic efficiency of $\mathrm{Gr} / \mathrm{SnO}_{2}$ composites prepared by Othmen et al. for the degradation of rhodamine B was $93 \%$.

The addition of Gr can increase the specific surface area of composite materials, intensify the carrier transfer between gas and composite materials, and enhance the sensitivity of gas detection. Several research groups have prepared various $\mathrm{Gr} /$ metal oxide composite materials able to detect different gases [62-64]. Of particular interest is a composite sensor prepared by Choi et al. that can detect $\mathrm{H}_{2} \mathrm{~S}$ and acetone gas; this sensor has been used to detect diabetes.

(2) Graphene/Ceramic Composite Materials. Table 4 presents a brief summary of the properties and preparation methods of $\mathrm{Gr} /$ ceramic composite materials.

Currently, the number of studies on Gr/ceramic composite materials is smaller than that of studies on $\mathrm{Gr} /$ metal composite materials. Table 4 shows these studies are primarily focused within the fields of mechanics and on the electrical and thermal properties of the composite materials. After the addition of $\mathrm{Gr}$ to ceramic materials, the resistance against force conduction can prevent the diffusion of cracks, resulting in a toughening effect. The toughening mechanism is summarized by Ahmad et al. [74]. Securely anchored Gr around the matrix can form large area of interfaces with the matrix, increasing the interfacial friction; therefore the energy required for pulling out $\mathrm{Gr}$ from the matrix will be greater. The fracture toughness of the $\mathrm{Gr} / \mathrm{Al}_{2} \mathrm{O}_{3}$ ceramic composite material prepared by Ahmad et al. [66] was $72 \%$ higher than that of the pure $\mathrm{Al}_{2} \mathrm{O}_{3}$ ceramic.

At present, the use of $\mathrm{Gr}$ to enhance the electrical properties of ceramics remains in the research stage. The electrical and thermal conductivities of composite materials are obviously affected by the paths constructed by $\mathrm{Gr}$ in the matrix. Lin et al. [72] and Xia et al. [73] determined the addition of $\mathrm{Gr}$ reduces the thermal conductivity of the composite. In addition, the electrical conductivity of $\mathrm{Gr} / \mathrm{B}_{4} \mathrm{C}$ prepared by Tan et al. [70] was $5000 \mathrm{~S} / \mathrm{m}$.

There is an intensely research interest in hybrid ceramic composites. The addition of nanoparticles greatly enhances the mechanical properties of hybrid composites. Better mechanical properties are correlated with distinctive 
TABLE 4: Properties and preparation methods of graphene/ceramic composite materials.

\begin{tabular}{|c|c|c|c|c|c|}
\hline Properties & Composition & $\begin{array}{l}\text { Preparation } \\
\text { method }\end{array}$ & $\begin{array}{l}\text { Loading of } \\
\text { Gr }\end{array}$ & Result(s) after addition of Gr & Reference \\
\hline \multirow{4}{*}{ Mechanical } & $\mathrm{Gr} / \mathrm{Al}_{2} \mathrm{O}_{3}$ & Sintering & 1.0 wt. $\%$ & $\begin{array}{c}\text { Bending strength and fracture toughness were } 26.4 \% \text { and } 67.6 \% \\
\text { higher than those of pure } \mathrm{Al}_{2} \mathrm{O}_{3} \text { ceramic }\end{array}$ & {$[65]$} \\
\hline & $\mathrm{Gr} / \mathrm{Al}_{2} \mathrm{O}_{3}$ & Sintering & 0.5 wt. $\%$ & $\begin{array}{c}\text { Fracture toughness was } 72 \% \text { higher than that of pure } \mathrm{Al}_{2} \mathrm{O}_{3} \\
\text { ceramic }\end{array}$ & {$[66]$} \\
\hline & $\mathrm{Gr} / \mathrm{Si}_{3} \mathrm{~N}_{4}$ & Sintering & 1.5 vol. $\%$ & $\begin{array}{c}\text { Fracture toughness was } 57.5 \% \text { higher than that of composite } \\
\text { material }\end{array}$ & [67] \\
\hline & Gr/AlN & Sintering & 1.49 vol. $\%$ & $\begin{array}{l}\text { Bending strength and fracture toughness were } 17.28 \% \text { and } 30.17 \% \text {, } \\
\text { respectively, higher than those of pure AlN ceramic }\end{array}$ & {$[68]$} \\
\hline \multirow{3}{*}{ Electrical } & $\mathrm{Gr} / \mathrm{Al}_{2} \mathrm{O}_{3}$ & Sintering & 15 vol. $\%$ & $\begin{array}{l}\text { Electrical conductivity parallel to voltage direction reached } 5709 \\
\qquad \mathrm{~S} / \mathrm{m}\end{array}$ & [69] \\
\hline & $\mathrm{Gr} / \mathrm{B}_{4} \mathrm{C}$ & Sintering & 4 vol.\% & $\begin{array}{l}\text { Electrical conductivities perpendicular and parallel to voltage } \\
\text { direction were } 5000 \pm 26 \mathrm{~S} / \mathrm{m} \text { and } 3250 \pm 22 \mathrm{~S} / \mathrm{m} \text {, respectively }\end{array}$ & {$[70]$} \\
\hline & $\mathrm{Gr} / \mathrm{Si}_{3} \mathrm{~N}_{4}$ & Sintering & 25 vol. $\%$ & $\begin{array}{l}\text { Maximum electrical conductivity perpendicular to the pressed } \\
\text { direction was } 4000 \mathrm{~S} / \mathrm{m}\end{array}$ & {$[71]$} \\
\hline \multirow{2}{*}{ Thermal } & $\mathrm{Gr} / \mathrm{Al}_{2} \mathrm{O}_{3}$ & Sintering & 8.5 vol. $\%$ & $\begin{array}{l}\text { Thermal conductivity decreased from } 32 \mathrm{~W} / \mathrm{mK}\left(\mathrm{Al}_{2} \mathrm{O}_{3} \text { ceramic }\right) \\
\text { to } 20 \mathrm{~W} / \mathrm{mK}\end{array}$ & {$[72]$} \\
\hline & Gr/AlN & Sintering & 2 wt.\% & $\begin{array}{c}\text { Thermal conductivity decreased from } 92.5 \mathrm{~W} / \mathrm{mK} \text { (AIN ceramic) } \\
\text { to } 37.4 \mathrm{~W} / \mathrm{mK}\end{array}$ & {$[73]$} \\
\hline
\end{tabular}

toughening mechanisms of crack-deflection as well as crackbridging induced by reinforcing phases upon establishing sturdy interfaces with the alumina matrix. The pull-out effect of nanoparticle is also taken into consideration. Ahmad et al. [75] prepared alumina $\left(\mathrm{Al}_{2} \mathrm{O}_{3}\right)$ ceramic matrix with silicon carbide nanoparticles $\left(\mathrm{SiC}_{\mathrm{NP}}\right)$ and graphene nanoplatelets (Gr). The fracture toughness and microhardness improved by $160 \%$ and $27 \%$, respectively. In addition, Ahmad and Islam [76] prepared inductively sintered alumina ceramic hybrid nanocomposites with 4 vol.\% multiwalled carbon nanotubes (mwCNT) and $6 \mathrm{vol} . \% \mathrm{SiC}_{\mathrm{NP}}$. Homogenously dispersed reinforcing inclusions led hybrid nanocomposites to respective $81 \%$ and $25 \%$ higher fracture toughness and microhardness over the monolithic alumina. Some researchers have studied the application of hybrid ceramic composites in the field of corrosion resistance and wear resistance. Graphene nanoplatelet-coated $\mathrm{B}_{4} \mathrm{C}$ reinforced $\mathrm{Al}$ Si matrix semiceramic hybrid composites were prepared by Polat et al. [77]. When the boron carbide surface was coated with 0.5 vol. $\%$ Gr, it was determined that the specific wear resistance increased by $55 \%$ and the corrosion resistance decreased by $12 \%$.

(3) Graphene/Other Inorganic Composite Materials. The application of $\mathrm{Gr}$ in the field of electrochemistry, optics, and catalysis can also be expanded after compositing with other inorganic materials. Geng et al. [78] prepared GO/CdSe quantum-dot composites and a flexible light-transmitting conductive film device, which had a light sensitivity and photoelectric conversion efficiency four- and tenfold, respectively, higher than those of pure CdSe quantum dots. Gao et al. [79] prepared GO/CdS composites via a self-assembly process. The GO/CdS composites exhibited highefficiency photocatalytic degradation and antibacterial effects for several types of sewage under visible light irradiation, which was different from the results obtained for pure CdS nanoparticles. Yu et al. [80] prepared CdTe quantum-dot/Gr nanocomposites, and the prepared electrodes exhibited excellent electrochemical catalytic activity, good biocompatibility, and high sensitivity for detecting the oxidation of uric acid (UA) and dopamine (DA).

\subsection{Graphene/Polymer Composite Materials}

3.2.1. Preparation of Graphene/Polymer Composite Materials. At present, the preparation of Gr/polymer composite materials can be divided into the following dispersion methods: in situ polymerization, melt blending, and solution blending. Table 5 presents a summary of these methods. Among the three methods, in situ polymerization is the most complicated because its reaction process is difficult to control and it has fewer applications than melt blending and solution blending. Melt blending is easily industrialized, and solution blending provides a uniform dispersion.

\subsubsection{Applications of Graphene/Polymer Composite Materials}

(1) Graphene/Conventional Thermoplastic Composite Materials

(i) Conventional plastics

Table 6 provides a summary of the properties and preparation methods of Gr/conventional thermoplastic composite materials.

Because of its high theoretical strength, Gr has been used as a reinforcing filler for most conventional plastics. Table 6 shows how a small amount of $\mathrm{Gr}$ effectively enhanced the strength and modulus of polyolefin materials [84-87]. For example, the mechanical strength of functionalized-RGO/poly(vinylidene fluoride) (F-RGO/PVDF) films prepared by Luo et al. was $42 \%$ higher than that of conventional RGO/PVDF films. 
TABLE 5: Preparation methods, advantages, disadvantages, and the scope of applications of graphene/polymer composite materials [81-83].

\begin{tabular}{|c|c|c|c|}
\hline $\begin{array}{l}\text { Preparation } \\
\text { method }\end{array}$ & Advantages & Disadvantages & Scope of applications \\
\hline $\begin{array}{l}\text { In situ } \\
\text { polymerization }\end{array}$ & $\begin{array}{l}\text { Uniform dispersion; achievement of } \\
\text { product control via changes in reaction } \\
\text { conditions }\end{array}$ & $\begin{array}{l}\text { Control issues from the cooperative } \\
\text { effect caused by reaction temperature, } \\
\text { among other factors; complicated } \\
\text { reaction, making industrialization } \\
\text { relatively difficult }\end{array}$ & $\begin{array}{l}\text { Various polymer-based composite } \\
\text { materials in extensive fields }\end{array}$ \\
\hline Solution mixing & $\begin{array}{l}\text { Uniform dispersion; beneficial method } \\
\text { for achieving obvious enhancement of } \\
\text { desirable properties }\end{array}$ & $\begin{array}{l}\text { Residual solvent, difficult recycling } \\
\text { process, and environmental pollution; } \\
\text { no suitability for scaled manufacturing }\end{array}$ & $\begin{array}{l}\text { Wide applications, various polymer- } \\
\text { based Gr composite materials, high- } \\
\text { insulation materials and coatings }\end{array}$ \\
\hline Melt blending & $\begin{array}{l}\text { Compliance with nonhazardous } \\
\text { solvent use and polar and nonpolar } \\
\text { polymers; simple operation and easy } \\
\text { achievement of industrialization }\end{array}$ & $\begin{array}{l}\text { Poor dispersion properties, facile dust } \\
\text { formation }\end{array}$ & $\begin{array}{l}\text { Composite materials with } \\
\text { thermoplastic matrices; applications } \\
\text { in the field of electrical and thermal } \\
\text { conduction (but still in the stage of } \\
\text { marketing promotion) }\end{array}$ \\
\hline
\end{tabular}

TABLE 6: Properties and preparation methods of composite materials comprising graphene and conventional polyolefin or its derivatives.

\begin{tabular}{|c|c|c|c|c|c|}
\hline Properties & Types & $\begin{array}{l}\text { Preparation } \\
\text { method }\end{array}$ & $\begin{array}{l}\text { Loading of } \\
\text { Gr }\end{array}$ & Result(s) after addition of $\mathrm{Gr}$ & Reference \\
\hline \multirow{4}{*}{ Mechanical } & $\begin{array}{l}\text { Partially RGO/(polypropylene/ethylene } \\
\text { propylene rubber) ((pRGO)/(PP/EPR)) }\end{array}$ & Melt blending & $2.0 \mathrm{wt} . \%$ & $\begin{array}{l}\text { Tensile strength and Young's modulus } \\
\text { were enhanced }\end{array}$ & [84] \\
\hline & Alkyl-graphene nanoplatelets (GNPs)/PP & Melt blending & $0.5 \mathrm{phr}$ & $\begin{array}{l}\text { Bending modulus, which affects } \\
\text { strength and energy-storage modulus, } \\
\text { was enhanced }\end{array}$ & [85] \\
\hline & $\begin{array}{c}\text { Carbon nanotubes } \\
(\mathrm{CNTs}) / \mathrm{Gr} / \text { polystyrene (PS) }\end{array}$ & $\begin{array}{l}\text { Solution } \\
\text { blending }\end{array}$ & - & \multirow{2}{*}{$\begin{array}{l}\text { Glass transition temperature (Tg), } \\
\text { modulus, and hardness were enhanced } \\
\text { Tensile strength was } 42 \% \text { higher than } \\
\text { that of conventional RGO/PVDF } \\
\text { composite films }\end{array}$} & {$[86]$} \\
\hline & $\begin{array}{l}\text { Functionalized-RGO/poly(vinylidene } \\
\text { fluoride) (F-RGO/PVDF) }\end{array}$ & $\begin{array}{l}\text { Solution } \\
\text { blending }\end{array}$ & - & & [87] \\
\hline \multirow{3}{*}{ Thermal } & Gr/polyethylene (PE) & Melt blending & 10.0 wt.\% & \multirow{3}{*}{$\begin{array}{c}\text { Thermal conductivity reached } \\
1.84 \mathrm{~W} / \mathrm{mK} \\
\text { Thermal conductivity increased from } \\
10.15 \text { to } 36.81 \mathrm{~W} / \mathrm{mK} \\
\text { Thermal conductivity was enhanced } \\
\text { by } 132.5 \%\end{array}$} & [88] \\
\hline & Gr/polyvinyl alcohol (PVA) & $\begin{array}{l}\text { Solution } \\
\text { blending }\end{array}$ & $20-65$ wt. $\%$ & & [89] \\
\hline & $\mathrm{GO} / \mathrm{PVDF}$ & Melt blending & 1.0 wt.\% & & {$[90]$} \\
\hline \multirow{4}{*}{ Electrical } & GO/PVA/PVP (polyvinylpyrrolidone) & $\begin{array}{l}\text { Solution } \\
\text { blending }\end{array}$ & - & $\begin{array}{l}\text { Electrical conductivity was } \\
\quad 6.13 \times 10-4 \mathrm{~S} / \mathrm{cm}\end{array}$ & [91] \\
\hline & $\begin{array}{c}\text { Large-area RGO/poly (vinylidene } \\
\text { fluoride-co-hexafluoropropylene) (rLGO/ } \\
\text { PVDF-HFP) }\end{array}$ & $\begin{array}{l}\text { Solution } \\
\text { blending }\end{array}$ & 27.2 wt. $\%$ & $\begin{array}{l}\text { Electrical conductivity was } \\
653000 \mathrm{~S} / \mathrm{m}\end{array}$ & {$[92]$} \\
\hline & Poly(ethylene glycol)- (PEG-) Gr/PVDF & $\begin{array}{l}\text { Solution } \\
\text { blending }\end{array}$ & 15 wt. $\%$ & $\begin{array}{c}\text { Electrically active crystal content was } \\
\text { increased by } 65.9 \%\end{array}$ & {$[93]$} \\
\hline & Few layer graphene (FLG)/PVDF & $\begin{array}{l}\text { Solution } \\
\text { blending }\end{array}$ & $1-90$ wt.\% & Electrical conductivity was $81.9 \mathrm{~S} / \mathrm{cm}$ & {$[94]$} \\
\hline \multirow{2}{*}{ Insulating } & $\begin{array}{l}\text { Hexadecylamine-functionalized Gr sheet } \\
\text { (HDA-GS)/PVA }\end{array}$ & $\begin{array}{l}\text { Solution } \\
\text { blending }\end{array}$ & $5.0 \mathrm{wt} . \%$ & \multirow{2}{*}{$\begin{array}{l}\text { Oxygen permeation coefficient was } \\
\text { reduced by } 81 \% \\
\text { Oxygen permeation coefficient was } \\
\text { reduced by } 35 \%\end{array}$} & [95] \\
\hline & Thermally reduced GO (TRGO)/PP & Melt blending & 1.0 wt. $\%$ & & [96] \\
\hline \multirow{3}{*}{ Medical } & $\begin{array}{l}\text { GO/ultra-high-molecular-weight } \\
\text { polyethylene (UHMWPE) }\end{array}$ & $\begin{array}{l}\text { Solution } \\
\text { blending }\end{array}$ & 2.0 wt. $\%$ & $\begin{array}{l}\text { Wear reduced significantly; good } \\
\text { biocompatibility achieved at all } \\
\text { concentrations studied }\end{array}$ & [97] \\
\hline & GO/high-density PE/UHMWPE & Melt blending & 1.0 wt. $\%$ & $\begin{array}{l}\text { Tensile strength and modulus and } \\
\text { biocompatibility were enhanced }\end{array}$ & [98] \\
\hline & $\begin{array}{l}\text { Mechanically exfoliated graphene } \\
\text { (MEG)/PVA }\end{array}$ & Gel spinning & 0.3 wt. $\%$ & $\begin{array}{l}\text { High strength, good antibacterial } \\
\text { performance, and low cytotoxicity } \\
\text { were achieved }\end{array}$ & [99] \\
\hline \multirow{3}{*}{ Other } & GNPs/PP & Melt blending & 0.5 wt. $\%$ & \multirow{3}{*}{$\begin{array}{l}\text { Aging of PP matrix was slowed } \\
\text { Organic material in wastewater was } \\
\text { effectively removed } \\
\text { Excellent fire retardancy of coated } \\
\text { PVA films was achieved }\end{array}$} & {$[100]$} \\
\hline & $\begin{array}{l}\text { GO/PP-g-poly[2-(dimethylamino)ethyl } \\
\text { methacrylate (DMAEMA) }\end{array}$ & Self-assembly & - & & {$[101]$} \\
\hline & Functionalized GO (FGO)/PVA & Self-assembly & - & & {$[102]$} \\
\hline
\end{tabular}


Gr has also been used to enhance the electrical and thermal conductivities of polyolefin materials. In general, the required $\mathrm{Gr}$ content is higher than 10 wt.\% because only a large amount of $\mathrm{Gr}$ forms electrically conductive and thermally conductive paths in polymer matrices [88-94]. For example, the thermal conductivity of the Gr/polyvinyl alcohol (PVA) prepared by Liu et al. was approximately $260 \%$ that of PVA. In addition, the electroactive crystal content of poly(ethylene glycol)- (PEG-) Gr/ PVDF prepared by Chen et al. was $65.9 \%$ higher than that of the matrix alone.

Because of its sheet structure, Gr has been used to enhance the insulating properties of polyolefin materials. Chang [95] prepared a hexadecylaminefunctionalized Gr sheet/polyvinyl alcohol (HDAGS)/PVA composite and found that an HDA-GS loading of $5 \mathrm{wt} . \%$ resulted in a $81 \%$ reduction in the oxygen transmission coefficient compared with that of PVA alone.

Because the addition of Gr enhances the strength of composite materials, several researchers combined it with several biocompatible polyolefin materials to fabricate biomedical materials with high biocompatibility and good antibacterial properties [97-99]. For example, Gowland et al. prepared GO/ ultra-highmolecular-weight polyethylene (UHMWPE) composite materials for use in the replacement of bone joints.

In addition, $\mathrm{Gr}$ /polyolefin composite materials have potential applications in various fields, including uses in antiaging and flame-retardant materials [100-102].

(ii) Conventional engineering plastics

(a) Gr/polyamide composite materials

The blending of $\mathrm{Gr}$ and polyamide (PA) was performed to enhance the electrical conductivity of PA. Ma et al. [103] and Xiang et al. [104] prepared polycaprolactam/thermally reduced GO composite materials (PA6/TRGO) and found these materials possessed an ultralow threshold for percolation flow. In addition, both groups showed significant increases in electrical conductivity compared with that of PA alone. In addition, $\mathrm{Gr}$ has been used to improve the permeability of PA-based reverse osmosis (RO) films. Shi et al. [105] prepared a GO/PA ultrathin film with excellent properties useful for the desalting process of RO films as well as excellent stability and remarkable permeability. Lai et al. [106] embedded GO nanosheets (GONS) into ultrathin crosslinked PA layers. After the addition of $0.02 \mathrm{~g} / \mathrm{m}^{2} \mathrm{GO}$, the removal rates of the obtained thin-film nanocomposite (TFN) membranes were $95.8 \%$ and $97.7 \%$ for $\mathrm{Na}_{2} \mathrm{SO}_{4}$ and $\mathrm{MgSO}_{4}$, respectively.
Because of the excellent flexibility of PA, Yin et al. [107] used PA to prepare flexible skin-like pressure sensors using Gr/PA interlocked fabrics that could be used in the preparation of artificial electronic skin and wearable electronic devices.

(b) Graphene/polyester composite materials $\mathrm{Gr}$ has been used to increase the sensing efficiency of Gr/polyester composites. Wang et al. [108] prepared a multifunctional RGO/poly(ethylene terephthalate) (PET) fabric. When it was used in a strain sensor, the RGO/PET fabric exhibited high sensitivity, demonstrating its great potential for use in the development of wearable smart devices. Seo et al. [109] coated PET with a graphene nanoplatelet- (GNP-) polyaniline composite material for the fabrication of a flexible sensor for detecting hazardous chemicals.

In addition, $\mathrm{Gr}$ has been used to enhance the heat resistance of polyester materials and fire retardancy when composited with specific materials. Xing et al. [110] used low-molecularweight poly(ethylene terephthalate) (PET-) grafted GONS to improve the compatibility between GO and PET, which simultaneously improved the thermal stability and crystallization properties of PET. Qi et al. [111] prepared an aluminum hypophosphite/RGO (AHP/RGO) hybrid flame-retardant material with high thermal stability. The AHP/RGO exhibited better flame retardancy than neat AHP for use with poly(butylene terephthalate) (PBT).

(c) Graphene/polycarbonate composite materials The addition of $\mathrm{Gr}$ to polycarbonate (PC) materials has been used for electromagnetic shielding. Bagotia et al. [112] added in situ RGO (IRGO) to a PC/ethylene-methyl acrylate (EMA) matrix, and the resultant mechanical hardness of the composite material was significantly higher than that of PC/EMA. When the IRGO content was $15 \mathrm{phr}$, the best effects from electromagnetic shielding were achieved in the X-band frequency range $(8.2-12.4 \mathrm{GHz})$. In addition, $\mathrm{Gr}$ has been used to enhance the solvent resistance of PC. Wang et al. [113] prepared superhydrophobic and superhydrophilic porous RGO/PC single-sheet composite materials that were able to adsorb a variety of oils and organic solvents from water.

Furthermore, Gr/PC composites have demonstrated their use for potential applications in smart materials. Leeladhar and Singh [114] prepared a GO/PC composite material with a double-layer structure that exhibited a smart response to infrared light. Therefore, the composite material was able to act as a light actuator, 
which could be used in applications such as sunlight-driven curtains, infrared light-driven curtains, and boxes that automatically fold upon exposure to light.

(d) Graphene/polyphenylene ether

$\mathrm{Gr}$ has been used to enhance the dielectric properties of polyphenylene ether. Wang et al. [115] prepared TRGO-coated calcium titanate (CCTO) as a filler material for polyphenylene ether. After the addition of 30 wt. $\%$ pf Gr-coated CCTO (g-CCTO), the dielectric constant of the resulting composite material was 8.60. Notably, the dielectric constant of the untreated CCTO/ polyphenylene oxide (PPO) composite was 7.08. $\mathrm{Gr} /$ polyphenylene ether has potential applications in the gas separation and capture of carbon dioxide. Rea et al. [116] prepared Gr/PPO composites. The composites containing a small amount of $\mathrm{Gr}$ possessed higher permeability and higher $\mathrm{He} / \mathrm{CO}_{2}$ selectivity than pure PPO.

(e) Graphene/polyurethane

The addition of $\mathrm{Gr}$ has been used to enhance the performance of polyurethane (PU) coatings and adhesives. Mohammadi et al. [117] prepared an environmentally friendly GO/hydrophilic PU nanocomposite (WPU/GO) with a $99.8 \%$ antiseptic inhibition efficiency. In addition, Wan and Chen [118] fabricated self-repairing GO/ hydrophilic PU nanocomposites via solution blending. The resulting nanocomposite possessed good thermal stability and mechanical properties and could be used in coatings and adhesives.

Several research groups showed Gr/PU composite materials have potential applications in controlling water pollution. Zhou et al. [119] prepared anthraquinone-2-sulfonate-RGO-PU foam (AQS-RGO-PUF) and showed AQS-RGOPUF possessed a superior catalytic performance for the biodecoloration of acid red 18 (AR18) compared with the performance of PUF alone. In addition, the combination of the Shewanella strain with AQS-RGO-PUF enhanced the treatment efficiency for azo dye-containing wastewater. Xia et al. [120] prepared superhydrophobic RGO-coated PU (RGO@PU) sponges with a high oil-absorption rate (oil removal occurred within 5 seconds) and a high oilwater separation efficiency (approximately 99\%).

(iii) Graphene/biodegradable polymer composite materials Table 7 provides a summary of the properties and preparation methods of composite materials comprising $\mathrm{Gr}$ and biodegradable polymers.

The majority of biodegradable polymers exhibit excellent biocompatibility, and their potential applications in the biomedical field can be expanded upon reinforcement with Gr. Table 7 shows the majority of $\mathrm{Gr} /$ biodegradable materials possess good biocompatibility and high bacterial resistance and promote the regeneration of tissue and bone. The PCL/GNS bracket prepared by Caetane et al. [134] significantly promoted cell proliferation and bone regeneration.

The two-dimensional structure of $\mathrm{Gr}$ has been used to enhance the isolation performance of biodegradable composite materials. Previously, our research group prepared a PLA/GO composite material, and the experimental results indicated the introduction of only a small amount of GO enhanced the isolation performance of PLA. You et al. [121] prepared a composite nanofilm containing poly(3-hydroxybutyric acid-co-3-hydroxyvaleric acid)/GO (PHBV/GO) and found the oxygen permeability coefficient was $48 \mathrm{~cm}^{3} /\left(\mathrm{m}^{2}\right.$.day) when the GO loading was $2.0 \mathrm{wt}$ \%, which was lower than that of PHBV alone.

In addition to the above findings, the addition of $\mathrm{Gr}$ to biodegradable polymers has been applied in electrical materials, fire retardant materials, sensors and catalysts, etc. $[123,124,126,127]$. However, the number of studies in these fields is relatively few, and further study on the enhancement of relevant properties is needed.

\section{(2) Graphene/Conventional Thermoset Plastics}

(i) Graphene/unsaturated polyester

When $\mathrm{Gr}$ exhibits good dispersibility within a polymer matrix, Gr acts as a reinforcing filler with excellent mechanical properties. He et al. [136] synthesized GO and GO derivatives containing vinyl and alkyl functional groups (mGO) and dispersed these substrates in unsaturated polyester resin (UPR) to fabricate composite nanomaterials. The fracture energy (G IC) was 55\% higher than that of neat GO when the loading of mGO was 0.04 wt.\%.

In addition, $\mathrm{Gr}$ has been used to enhance the fire retardancy of thermoset materials such as UPR. Jiang et al. [137] first synthesized a novel organophosphorus oligomer (DHP) and then prepared the G-DHP composite material. The introduction of 2.0 wt.\% G-DHP significantly enhanced the fire retardancy of the UPR matrix, which was demonstrated by a $41.79 \%$ decrease in the peak exothermic rate (PHRR).

(ii) Graphene/phenolic resin

Traditional phenolic resin $(\mathrm{PF})$ cannot meet the necessary performance requirements, especially those needed for the ablation resistance of advanced aerospace vehicles because PF is easily oxidized. Lv et al. [138] prepared $\mathrm{SiO}_{2} / \mathrm{RGO} / \mathrm{PF}$ binary hybrid nanomaterials to help oxidize $\mathrm{PF}$. When the content of the dispersed $\mathrm{SiO}_{2}$ nanoparticles on graphene (GS) was 3 wt.\%, the 3 wt.\% of G-S (P-G-S-3) exhibited 
TABLE 7: Properties and preparation methods of composite materials comprising graphene and biodegradable polymers.

\begin{tabular}{|c|c|c|c|c|}
\hline Composition & $\begin{array}{l}\text { Preparation } \\
\text { method }\end{array}$ & Loading of $\mathrm{Gr}$ & Result(s) after addition of Gr & Reference \\
\hline $\begin{array}{l}\text { GO/poly(3-hydroxybutric acid-co-3- } \\
\text { hydroxyvaleric acid (PHBV) }\end{array}$ & $\begin{array}{l}\text { Solution } \\
\text { blending }\end{array}$ & 2.0 wt. $\%$ & $\begin{array}{l}\text { Oxygen permeation rate decreased from } \\
63 \mathrm{~cm}^{3} /\left(\mathrm{m}^{2} \text {.day }\right) \text { to } 48 \mathrm{~cm}^{3} /\left(\mathrm{m}^{2} \cdot \text { day }\right)\end{array}$ & {$[121]$} \\
\hline $\mathrm{GO} /$ collagen/PHBV & $\begin{array}{l}\text { Solution } \\
\text { blending }\end{array}$ & 0.3 wt. $\%$ & $\begin{array}{l}\text { High mechanical strength and good antibacterial } \\
\text { performance, necessary for covering wounds, were } \\
\text { achieved }\end{array}$ & {$[122]$} \\
\hline $\begin{array}{l}\text { Functionalized graphene sheets } \\
\text { (FGS)/PHBV }\end{array}$ & Ball milling & $0.1-3.0$ wt. $\%$ & $\begin{array}{l}\text { High gas resistance and low percolation threshold, } \\
\text { significantly enhanced electric conductivity }\end{array}$ & [123] \\
\hline $\begin{array}{l}\text { FGO-hydroxyquinoline/poly(lactic } \\
\text { acid) (FGO-HQ/PLA) }\end{array}$ & Melt blending & 6.0 wt.\% & Excellent fire retardancy was achieved & {$[124]$} \\
\hline GO-g-poly-L-lactide (PLLA)/PLLA & $\begin{array}{l}\text { Solution } \\
\text { blending }\end{array}$ & $0.1-3.0$ wt. $\%$ & $\begin{array}{l}\text { High antibacterial activity was achieved; potential } \\
\text { for use in biomedical fields was demonstrated }\end{array}$ & [125] \\
\hline $\begin{array}{l}\text { Zeolitic imidazolate framework-8 } \\
\text { (ZIF-8)@GO/PLA }\end{array}$ & $\begin{array}{l}\text { Solution } \\
\text { blending }\end{array}$ & 3.0 wt.\% & $\begin{array}{l}\text { Tensile strength higher than that of pure PLA was } \\
\text { achieved; strong removal capability for methylene } \\
\text { blue was demonstrated }\end{array}$ & {$[126]$} \\
\hline Graphene nanorods (GNRs)/PLA & Melt blending & - & $\begin{array}{l}\text { Use in sensor that monitors common aquatic and } \\
\text { land environments was demonstrated }\end{array}$ & {$[127]$} \\
\hline Gr/PLA & Melt blending & 1.0 wt.\% & Oxygen permeation rate was reduced by $36 \%$ & [128] \\
\hline $\begin{array}{l}\text { GO with octadecylamine/polybutylene } \\
\text { succinate (GOODA/PBS) }\end{array}$ & $\begin{array}{l}\text { Solution } \\
\text { blending }\end{array}$ & 0.1 wt. $\%$ & $\begin{array}{l}\text { Tensile strength and Young's modulus were } \\
\text { enhanced by } 50 \% \text { and } 58.9 \% \text {, respectively }\end{array}$ & {$[129]$} \\
\hline $\begin{array}{l}\text { GONS/poly(butylene adipate-co- } \\
\text { terephthalate) (PBAT) }\end{array}$ & $\begin{array}{c}\text { Solution } \\
\text { coagulation }\end{array}$ & 0.35 vol. $\%$ & $\begin{array}{c}\text { Coefficients of permeability of } \mathrm{O}_{2} \text { and water vapor } \\
\text { were reduced by } 70 \% \text { and } 36 \% \text {, respectively }\end{array}$ & {$[130]$} \\
\hline GNPs/PBAT & Melt blending & $0-15.0$ vol. $\%$ & $\begin{array}{c}\text { Dielectric constant of polymer was enhanced } \\
\text { significantly }\end{array}$ & {$[131]$} \\
\hline RGO/polycaprolactone (PCL) & $\begin{array}{l}\text { Solution } \\
\text { blending }\end{array}$ & $0-0.1$ wt. $\%$ & $\begin{array}{c}\text { Regeneration of dental pulp stem cell (DPSC) } \\
\text { nerve was promoted }\end{array}$ & {$[132]$} \\
\hline Poly-D-glucosamine (PDG)/PCL & Melt blending & - & $\begin{array}{l}\text { Tensile and yield strengths were } 2.4 \text { - and } 2.6 \text {-fold, } \\
\text { respectively, those of PCL, indicative of self- } \\
\text { healing behavior }\end{array}$ & {$[133]$} \\
\hline GO/P1-latex protein/PCL & Melt blending & $0.13-0.78$ wt. $\%$ & $\begin{array}{l}\text { Gr/P1-latex/PCL protein bracket was used in bone } \\
\text { regeneration }\end{array}$ & {$[134]$} \\
\hline $\mathrm{Gr} / \mathrm{PCL}$ & Melt blending & $0.25-0.75$ wt. $\%$ & $\begin{array}{l}\text { Gr/PCL was demonstrated to be beneficial for } \\
\text { tissue formation and bone regeneration }\end{array}$ & [135] \\
\hline
\end{tabular}

a lower thermal oxidative decomposition rate and a higher termination temperature for thermal oxidative decomposition than neat PF.

$\mathrm{Gr} /$ phenolic resin composites have also been used as dielectric materials. Wu et al. [139] prepared threedimensional Gr network/phenolic resin composite materials with adjustable and low negative dielectric constants. The results of this study showed negative dielectric constants could be controlled by controlling the Gr content.

(iii) Graphene/epoxy resin composite materials

The addition of Gr was used to enhance the corrosion resistance of epoxy resin (ER). Zheng et al. [140], Mousavi et al. [141], and Yang et al. [142] prepared modified GO/ER composite materials able to obviously enhance the corrosion resistance of epoxy coatings on matrices.

Furthermore, the addition of Gr was used to enhance the fire retardancy of ER. Zhang et al. [143] studied the effect of graphene nanoplatelets (GNP) on the combustion properties of ER. The PHRR of GNP/ER composites was much lower than that of pure ER.

In addition, Gr was used to enhance the thermal conductivity of ER. Olowojoba et al. [144] prepared RGO/ER composite materials. When the RGO content was $0.06 \mathrm{wt} . \%$, the thermal conductivity of the composite material was $0.25 \mathrm{~W} / \mathrm{mK}$, which was $40 \%$ higher than that of unmodified ER.

\section{Prospects and Developmental Trends}

Because of the in-depth studies on Gr, the fundamental research and application of Gr composite materials have progressed and demonstrated Gr has significant application potential in the fields of aerospace, transportation, medical equipment, electrical and thermal conductive materials, and construction materials. In $\mathrm{Gr}$ /inorganic composites, $\mathrm{Gr}$ provides good mechanical strength and can be used as a structural material useful for compositing with elemental metals; sinter molding is generally adopted for these types of 
composites. For the compositing process between metal oxides and Gr, hydrothermal reduction or chemical reduction methods are usually adopted, and the resulting product is generally used in supercapacitors. Because of the unique two-dimensional structure of $\mathrm{Gr}$, it can also be used in sensors and catalysts. Ceramic/Gr composites are less studied than metal/Gr composites. Sintering is commonly adopted for the fabrication of ceramic/Gr composites, and these types of composites are generally used for structural reinforcement. For Gr/polymer composite materials, melt blending is advantageous for industrial production while solution blending or in situ polymerization may be more advantageous for laboratory preparations. Gr is able to combine with different polymers and provide significant advantages for the preparation of sensing materials, functional films, biomedical materials, and anticorrosion coatings, among other applications. However, several problems that must be solved remain. (1) The Gr preparation method of $\mathrm{Gr}$ is complicated and expensive; thus, inexpensive batch preparation is difficult. (2) The processing temperatures for inorganic materials such as metals and ceramics are high and could destroy the structure of Gr. Therefore, processing difficulty and cost are high when Gr and inorganic materials are composited. (3) When $\mathrm{Gr}$ is composited with organic polymers, Gr usually exists in the form of agglomerates because its specific surface area and surface free energy are large and strong electrostatic and Van der Waals forces exist between the Gr sheets. Agglomerates easily cause defects in the polymer composite, which is not conducive to enhancing its material properties. Therefore, the search for effective modification methods and the achievement of good dispersion and the stripping effect of $\mathrm{Gr}$ in polymer matrices are important prerequisites in the manufacturing of ideal nanocomposites. In the future, the preparation methods and structure-property relationships of Gr composite materials should be optimized so Gr composite materials can ultimately promote additional development in materials engineering.

\section{Conflicts of Interest}

The authors declare that they have no conflicts of interest.

\section{Acknowledgments}

The authors gratefully acknowledge the financial support provided by The National Science Foundation (project nos. 51773005, 51473006, and 51173005) and the Beijing Science Foundation (KZ201810011017).

\section{References}

[1] P. R. Wallace, "The band theory of graphite," Physical Review, vol. 71, no. 9, pp. 622-634, 1947.

[2] K. S. Novoselov, A. K. Geim, S. V. Morozov et al., "Electric field effect in atomically thin carbon films," Science, vol. 306, no. 5696, pp. 666-669, 2004.

[3] V. Singh, D. Joung, L. Zhai, S. Das, S. I. Khondaker, and S. Seal, "Graphene based materials: past, present and future,"
Progress in Materials Science, vol. 56, no. 8, pp. 1178-1271, 2011.

[4] R. Raccichini, A. Varzi, S. Passerini, and B. Scrosati, "The role of graphene for electrochemical energy storage," Nature Materials, vol. 14, no. 3, pp. 271-279, 2015.

[5] L. Gu, S. Liu, H. Zhao, and H. Yu, "Facile preparation of water-dispersible graphene sheets stabilized by carboxylated oligoanilines and their anticorrosion coatings," ACS Applied Materials \& Interfaces, vol. 7, no. 32, pp. 17641-17648, 2015.

[6] Z. Zhang, J. Sun, C. Lai, Q. Wang, and C. Hu, "High-yield ball-milling synthesis of extremely concentrated and highly conductive graphene nanoplatelet inks for rapid surface coating of diverse substrates," Carbon, vol. 120, pp. 411-418, 2017.

[7] V. P. Verma, S. Das, I. Lahiri, and W. Chio, "Large-area graphene on polymer film for flexible and transparent anode in field emission device," Applied Physics Letters, vol. 96, no. 20, Article ID 203108, 2010.

[8] Y. Zhu, H. Ji, H.-M. Cheng, and R. S. Ruoff, "Mass production and industrial applications of graphene materials," National Science Review, vol. 5, no. 1, pp. 90-101, 2018.

[9] K. Toda, R. Furue, and S. Hayami, "Recent progress in applications of graphene oxide for gas sensing: a review," Analytica Chimica Acta, vol. 878, pp. 43-53, 2015.

[10] N. Dubey, K. Ellepola, F. E. D. Decroix et al., "Graphene onto medical grade titanium: an atom-thick multimodal coating that promotes osteoblast maturation and inhibits biofilm formation from distinct species," Nanotoxicology, vol. 12, no. 4, pp. 274-289, 2018.

[11] D. G. Papageorgiou, I. A. Kinloch, and R. J. Young, "Mechanical properties of graphene and graphene-based nanocomposites," Progress in Materials Science, vol. 90, pp. 75-127, 2017.

[12] A. J. Muhammad, A. A. Rana, A. A. Abdulrahman, and M. Umair, "Photocatalysis and bandgap engineering using $\mathrm{ZnO}$ nanocomposites," Advances in Materials Science and Engineering, vol. 2015, Article ID 934587, 22 pages, 2015.

[13] X. M. Li, L. Tao, Z. F. Chen et al., "Graphene and related twodimensional materials: structure-property relationships for electronics and optoelectronics," Applied Physics Reviews, vol. 4, no. 2, Article ID 021306, 2017.

[14] Y. Kim, T. K. An, J. Kim et al., "A composite of a graphene oxide derivative as a novel sensing layer in an organic fieldeffect transistor," Journal of Materials Chemistry C, vol. 2, no. 23, pp. 4539-4544, 2014.

[15] X. D. Xia, J. Hao, Y. Wang et al., "Theory of electrical conductivity and dielectric permittivity of highly aligned graphene-based nanocomposites," Journal of Physics: Condensed Matter, vol. 29, no. 20, Article ID 205702, 2017.

[16] Z. Y. Fan, L. F. C. Pereira, P. Hirvonen et al., "Thermal conductivity decomposition in two-dimensional materials: application to graphene," Physical Review B: Condensed Matter and Materials Physics, vol. 95, no. 14, Article ID 144309, 2017.

[17] R. Tu, Y. Liang, C. Zhang et al., "Fast synthesis of highquality large-area graphene by laser CVD," Applied Surface Science, vol. 445, pp. 204-210, 2018.

[18] K. Yan, L. Fu, H. L. Peng, and Z. F. Liu, "Designed CVD growth of graphene via process engineering," Accounts of Chemical Research, vol. 46, no. 10, pp. 2263-2274, 2013.

[19] S. J. Gu, X. Zhou, T. J. Lin et al., "Broadband non-contact characterization of epitaxial graphene by near-field microwave microscopy," Nanotechnology, vol. 28, no. 33, Article ID 335702, 2017. 
[20] P. J. Luxmi, N. Srivastava, R. M. Feenstra, and P. J. Fisher, "Formation of epitaxial graphene on $\mathrm{SiC}(0001)$ using vacuum or argon environments," Journal of Vacuum Science \& Technology B, Nanotechnology and Microelectronics: Materials, Processing, Measurement, and Phenomena, vol. 28, no. 4, pp. C5C1-C5C7, 2010.

[21] J. P. Rourke, P. A. Pandey, J. J. Moore et al., "The real graphene oxide revealed: stripping the oxidative debris from the graphene-like sheets," Angewandte Chemie International Edition, vol. 50, no. 14, pp. 3173-3177, 2011.

[22] Y. H. Lu, R. Q. Wu, L. Shen et al., "Effect of edge passivation by hydrogen on electronic structure of armchair graphene nanoribbon and band gap engineering," Applied Physics Letters, vol. 94, Article ID 122111, 2009.

[23] S. Sarkar, E. Bekyarova, S. Niyogi, and R. C. Haddon, "Diels-alder chemistry of graphite and graphene: graphene as diene and dienophile," Journal of the American Chemical Society, vol. 133, no. 10, pp. 3324-3327, 2011.

[24] Q. K. Yu, J. Lian, S. Siriponglert et al., "Graphene segregated on Ni surfaces and transferred to insulators," Applied Physics Letters, vol. 93, no. 11, Article ID 113103, 2008.

[25] Y. Li and N. Chopra, "Progress in large-scale production of graphene. Part 1: chemical methods," JOM, vol. 67, no. 1, pp. 34-43, 2015.

[26] J. Sturala, J. Luxa, M. Pumera, and Z. Sofer, "Chemistry of graphene derivatives: synthesis, applications, and perspectives," Chemistry-A European Journal, vol. 24, no. 23, pp. 5992-6006, 2018.

[27] W. Tu, J. Lei, S. Zhang, and H. Ju, "Characterization, direct electrochemistry, and amperometric biosensing of graphene by noncovalent functionalization with picket-fence porphyrin," Chemistry - A European Journal, vol. 16, no. 35, pp. 10771-10777, 2010.

[28] J. A. Mann and W. R. Dichtel, "Noncovalent functionalization of graphene by molecular and polymeric adsorbates," The Journal of Physical Chemistry Letters, vol. 4, no. 16, pp. 2649-2657, 2013.

[29] X. Jia, J. Campos-Delgado, M. Terrones, V. Meunier, and M. S. Dresselhaus, "Graphene edges: a review of their fabrication and characterization," Nanoscale, vol. 3, no. 1, pp. 86-95, 2011.

[30] T. Sun, H. Zou, Y. Zhou, R. Li, M. Liang, and Y. Chen, "Achieving high-performance epoxy nanocomposites with trifunctional poly(oxypropylene)amines functionalized graphene oxide," High Performance Polymers, vol. 31, no. 5, pp. 557-569, 2019.

[31] A. Kumar, K. Sharma, and A. R. Dixit, "A review of the mechanical and thermal properties of graphene and its hybrid polymer nanocomposites for structural applications," Journal of Materials Science, vol. 54, no. 8, pp. 5992-6026, 2019.

[32] M. Muschi and C. Serre, "Progress and challenges of graphene oxide/metal-organic composites," Coordination Chemistry Reviews, vol. 387, pp. 262-272, 2019.

[33] H. Porwal, P. Tatarko, S. Grasso, J. Khaliq, I. Dlouhý, and M. J. Reece, "Graphene reinforced alumina nano-composites," Carbon, vol. 64, no. 11, pp. 359-369, 2013.

[34] P. J. Sephra, P. Baraneedharan, M. Sivakumar, T. D. Thangadurai, and K. Nehru, "In situ growth of hexagonal-shaped $\alpha-\mathrm{Fe}_{2} \mathrm{O}_{3}$ nanostructures over few layered graphene by hydrothermal method and their electrochemical performance," Journal of Materials Science: Materials in Electronics, vol. 29, no. 8, pp. 6898-6908, 2018.
[35] J. Wang, X. Guo, Y. He et al., "Synthesis and tribological properties of graphene-copper nanoparticle composites as lithium grease additive," China Petroleum Processing \& Petrochemical Technology, vol. 19, pp. 113-122, 2017.

[36] A. Badr, M. Sadighi, H. Asgharzadeh, and T. Rabizadeh, "Enhancing the corrosion resistance of aluminum by graphene oxide and reduced graphene oxide films," Materials Research Express, vol. 6, no. 7, Article ID 075606, 2019.

[37] J. Hwang, T. Yoon, S. H. Jin et al., "Enhanced mechanical properties of graphene/copper nanocomposites using a molecular-level mixing process," Advanced Materials, vol. 25, no. 46, pp. 6724-6729, 2013.

[38] Y. Chen, X. Zhang, E. Liu et al., "Fabrication of three-dimensional graphene/Cu composite by in-situ CVD and its strengthening mechanism," Journal of Alloys and Compounds, vol. 688, pp. 69-76, 2016.

[39] P. Wang, W. Liu, L. Chen et al., "Bio-inspired laminated graphite nanosheets/copper composites," RSC Advances, vol. 5, no. 36, pp. 51342-51346, 2015.

[40] Z. Y. Zhao, R. G. Guan, X. H. Guan, Z. X. Feng, H. Chen, and $\mathrm{Y}$. Chen, "Microstructures and properties of graphene- $\mathrm{Cu} / \mathrm{Al}$ composite prepared by a novel process through clad forming and improving wettability with copper," Advanced Engineering Materials, vol. 17, no. 5, pp. 663-668, 2015.

[41] M. Bastwros, G.-Y. Kim, C. Zhu et al., "Effect of ball milling on graphene reinforced Al6061 composite fabricated by semi-solid sintering," Composites Part B: Engineering, vol. 60, no. 1, pp. 111-118, 2014.

[42] H. Rho, S. Lee, and S. Bae, "Three-dimensional porous copper-graphene heterostructures with durability and high heat dissipation performance," Scientific Reports, vol. 5, no. 1, Article ID 12710, 2015.

[43] P. Goli, H. Ning, X. Li, C. Y. Lu, K. S. Novoselov, and A. A. Balandin, "Thermal properties of graphene-coppergraphene heterogeneous films," Nano Letters, vol. 14, no. 3, pp. 1497-1503, 2014.

[44] Y.-T. Li, L.-L. Qu, D.-W. Li, Q.-X. Song, F. Fathi, and Y.-T. Long, "Rapid and sensitive in-situ detection of polar antibiotics in water using a disposable Ag-graphene sensor based on electrophoretic preconcentration and surface-enhanced Raman spectroscopy," Biosensors and Bioelectronics, vol. 43, no. 10, pp. 94-100, 2013.

[45] L. Ouyang, L. Yao, T. Zhou, and L. Zhu, "Accurate SERS detection of malachite green in aquatic products on basis of graphene wrapped flexible sensor," Analytica Chimica Acta, vol. 1027, pp. 83-91, 2018.

[46] S. Themsirimongkon, K. Ounnunkad, and S. Saipanya, "Electrocatalytic enhancement of platinum and palladium metal on polydopamine reduced graphene oxide support for alcohol oxidation," Journal of Colloid and Interface Science, vol. 530, pp. 98-112, 2018.

[47] X. Yan, H. Li, J. Sun et al., "Pt nanoparticles decorated highdefective graphene nanospheres as highly efficient catalysts for the hydrogen evolution reaction," Carbon, vol. 137, pp. 405-410, 2018.

[48] M. Li, L. Huang, X. Wang et al., "Direct generation of Ag nanoclusters on reduced graphene oxide nanosheets for efficient catalysis, antibacteria and photothermal anticancer applications," Journal of Colloid and Interface Science, vol. 529, pp. 444-451, 2018.

[49] M. Sheikhzadeh, S. Sanjabi, M. Gorji, and S. Khabazian, "Nano composite foam layer of $\mathrm{CuO} /$ graphene oxide (GO) for high performance supercapacitor," Synthetic Metals, vol. 244, pp. 10-14, 2018. 
[50] Y. Jiang, Y. Wan, W. Jiang et al., "Stabilizing the reversible capacity of $\mathrm{SnO}_{2}$ /graphene composites by $\mathrm{Cu}$ nanoparticles," Chemical Engineering Journal, vol. 367, pp. 45-54, 2019.

[51] H. Li, J. He, X. Cao et al., "All solid-state $\mathrm{V}_{2} \mathrm{O}_{5}$-based flexible hybrid fiber supercapacitors," Journal of Power Sources, vol. 371, pp. 18-25, 2017.

[52] N. Xu, J. Liang, T. Qian, T. Yang, and C. Yan, "Half-cell and full-cell applications of horizontally aligned reduced oxide graphene $/ \mathrm{V}_{2} \mathrm{O}_{5}$ sheets as cathodes for high stability lithium-ion batteries," RSC Advances, vol. 6, no. 101, pp. 98581-98587, 2016.

[53] H. Liu, W. Zhu, D. Long, J. Zhu, and G. Pezzotti, "Porous $\mathrm{V}_{2} \mathrm{O}_{5}$ nanorods/reduced graphene oxide composites for high performance symmetric supercapacitors," Applied Surface Science, vol. 478, pp. 383-392, 2019.

[54] X. Zhao, L. Zhang, S. Murali et al., "Incorporation of manganese dioxide within ultraporous activated graphene for high-performance electrochemical capacitors," ACS Nano, vol. 6, no. 6, pp. 5404-5412, 2012.

[55] W. Liu, X. Wang, L. Zhang, and J. Lian, "A novel interfacial synthesis of MnO-NiO-reduced graphene oxide hybrid with enhanced pseudocapacitance performance," RSC Advances, vol. 5, no. 67, pp. 54138-54147, 2015.

[56] G. Lin, Y. Jiang, C. He, Z. Huang, X. Zhang, and Y. Yang, "In situ encapsulation of $\mathrm{Co}_{3} \mathrm{O}_{4}$ polyhedra in graphene sheets for high-capacitance supercapacitors," Dalton Transactions, vol. 48, no. 17, pp. 5773-5778, 2019.

[57] W. B. Othmen, A. Hamdi, A. Addad et al., "Fe-doped $\mathrm{SnO}_{2}$ decorated reduced graphene oxide nanocomposite with enhanced visible light photocatalytic activity," Journal of Photochemistry and Photobiology A: Chemistry, vol. 367, pp. 145-155, 2018.

[58] J. Wang, G. Zhang, and P. Zhang, "Graphene-assisted photothermal effect on promoting catalytic activity of layered $\mathrm{MnO}_{2}$ for gaseous formaldehyde oxidation," Applied Catalysis B: Environmental, vol. 239, pp. 77-85, 2018.

[59] P. M. Martins, C. G. Ferreira, A. R. Silva et al., " $\mathrm{TiO}_{2} /$ graphene and $\mathrm{TiO}_{2}$ /graphene oxide nanocomposites for photocatalytic applications: a computer modeling and experimental study," Composites Part B: Engineering, vol. 145, pp. 39-46, 2018.

[60] E. Aawani, N. Memarian, and H. R. Dizaji, "Synthesis and characterization of reduced graphene oxide- $\mathrm{V}_{2} \mathrm{O}_{5}$ nanocomposite for enhanced photocatalytic activity under different types of irradiation," Journal of Physics and Chemistry of Solids, vol. 125, pp. 8-15, 2019.

[61] J.-X. Jiang, Q.-Q. Zhang, Y.-H. Li, and L. Li, "Three-dimensional network graphene aerogel for enhancing adsorption and visible light photocatalysis of nitrogen-doped $\mathrm{TiO}_{2}$," Materials Letters, vol. 234, pp. 298-301, 2019.

[62] Z. Li, Y. Liu, D. Guo, J. Guo, and Y. Su, "Room-temperature synthesis of $\mathrm{CuO} /$ reduced graphene oxide nanohybrids for high-performance $\mathrm{NO}_{2}$ gas sensor," Sensors and Actuators B: Chemical, vol. 271, pp. 306-310, 2018.

[63] S.-J. Choi, B.-H. Jang, S.-J. Lee, B. K. Min, A. Rothschild, and I.-D. Kim, "Selective detection of acetone and hydrogen sulfide for the diagnosis of diabetes and halitosis using $\mathrm{SnO}_{2}$ nanofibers functionalized with reduced graphene oxide nanosheets," ACS Applied Materials \& Interfaces, vol. 6, no. 4, pp. 2588-2597, 2014.

[64] S. Navazani, A. Shokuhfar, M. Hassanisadi, A. Di Carlo, and N. Shahcheraghi, "Fabrication and characterization of a sensitive, room temperature methane sensor based on $\mathrm{SnO}_{2} @$ reduced graphene oxide-polyaniline ternary nanohybrid," Materials Science in Semiconductor Processing, vol. 88, pp. 139-147, 2018.

[65] F. d. Río, M. G. Boado, A. Rama, and F. Guitián, “A comparative study on different aqueous-phase graphite exfoliation methods for few-layer graphene production and its application in alumina matrix composites," Journal of the European Ceramic Society, vol. 37, no. 12, pp. 3681-3693, 2017.

[66] I. Ahmad, M. Islam, H. S. Abdo et al., "Toughening mechanisms and mechanical properties of graphene nanosheet-reinforced alumina," Materials \& Design, vol. 88, pp. 1234-1243, 2015.

[67] L. S. Walker, V. R. Marotto, M. A. Rafiee et al., "Toughening in graphene ceramic composites," ACS Nano, vol. 5, no. 4, pp. 3182-3190, 2011.

[68] C. Yun, Y. Feng, T. Qiu, J. Yang, X. Li, and L. Yu, "Mechanical, electrical, and thermal properties of graphene nanosheet/aluminum nitride composites," Ceramics International, vol. 41, no. 7, pp. 8643-8649, 2015.

[69] Y. Fan, L. Wang, J. Li et al., "Preparation and electrical properties of graphene nanosheet $/ \mathrm{Al}_{2} \mathrm{O}_{3}$ composites," Carbon, vol. 48, no. 6, pp. 1743-1749, 2010.

[70] Y. Tan, H. Zhang, and S. Peng, "Electrically conductive graphene nanoplatelet/boron carbide composites with high hardness and toughness," Scripta Materialia, vol. 114, pp. 98-102, 2016.

[71] C. Ramirez, F. M. Figueiredo, P. Miranzo, P. Poza, and M. I. Osendi, "Graphene nanoplatelet/silicon nitride composites with high electrical conductivity," Carbon, vol. 50, no. 10, pp. 3607-3615, 2012.

[72] C.-J. Lin, I.-C. Lin, and W.-H. Tuan, "Effect of graphene concentration on thermal properties of alumina-graphene composites formed using spark plasma sintering," Journal of Materials Science, vol. 52, no. 3, pp. 1759-1766, 2017.

[73] H. Xia, X. Zhang, Z. Shi et al., "Mechanical and thermal properties of reduced graphene oxide reinforced aluminum nitride ceramic composites," Materials Science and Engineering: $A$, vol. 639, pp. 29-36, 2015.

[74] I. Ahmad, B. Yazdani, and Y. Zhu, "Recent advances on carbon nanotubes and graphene reinforced ceramics nanocomposites," Nanomaterials, vol. 5, no. 1, pp. 90-114, 2015.

[75] I. Ahmad, M. Islam, T. Subhani et al., "Toughness enhancement in graphene nanoplatelet/SiC reinforced $\mathrm{Al}_{2} \mathrm{O}_{3}$ ceramic hybrid nanocomposites," Nanotechnology, vol. 27, no. 42, Article ID 425704, 2016.

[76] I. Ahmad and M. Islam, "Reinforcing ability and bonding characteristics of multiwall carbon nanotubes and silicon carbide nanoparticles in inductively sintered alumina ceramic hybrid nanocomposites," Journal of Alloys and Compounds, vol. 788, pp. 219-230, 2019.

[77] S. Polat, Y. Sun, E. Çevik, H. Colijn, and M. E. Turan, "Investigation of wear and corrosion behavior of graphene nanoplatelet-coated $\mathrm{B} 4 \mathrm{C}$ reinforced Al-Si matrix semi-ceramic hybrid composites," Journal of Composite Materials, vol. 53, no. 25, pp. 3549-3565, 2019.

[78] X. Geng, L. Niu, Z. Xing et al., "Aqueous-processable noncovalent chemically converted graphene-quantum dot composites for flexible and transparent optoelectronic films," Advanced Materials, vol. 22, no. 5, pp. 638-642, 2010.

[79] P. Gao, J. Liu, D. D. Sun, and W. Ng, "Graphene oxide-CdS composite with high photocatalytic degradation and disinfection activities under visible light irradiation," Journal of Hazardous Materials, vol. 250-251, pp. 412-420, 2013.

[80] H.-w. Yu, J.-h. Jiang, Z. Zhang et al., "Preparation of quantum dots CdTe decorated graphene composite for 
sensitive detection of uric acid and dopamine," Analytical Biochemistry, vol. 519, pp. 92-99, 2017.

[81] Y. Luo, Y. Wu, K. Luo, F. Cai, T. Zhai, and S. Wu, "Structures and properties of alkanethiol-modified graphene oxide/solution-polymerized styrene butadiene rubber composites: click chemistry and molecular dynamics simulation," Composites Science and Technology, vol. 161, pp. 32-38, 2018.

[82] J. Ma, Y. Li, X. Yin et al., "Poly(vinyl alcohol)/graphene oxide nanocomposites prepared by in situ polymerization with enhanced mechanical properties and water vapor barrier properties," RSC Advances, vol. 6, no. 55, pp. 49448-49458, 2016.

[83] S. Adrar, A. Habi, A. Ajji, and Y. Grohens, "Combined effect of epoxy functionalized graphene and organomontmorillonites on the morphology, rheological and thermal properties of poly (butylenes adipate- co -terephtalate) with or without a compatibilizer," Applied Clay Science, vol. 146, pp. 306-315, 2017.

[84] R. Doufnoune and N. Haddaoui, "Effects of surface functionalized partially reduced graphene oxide and different compatibilizers on the properties and structure of PP/EPR nanocomposites," Journal of Polymer Research, vol. 24, no. 9, p. 138, 2017.

[85] S. M. Park and D. S. Kim, "Effect of alkyl chain length grafted to graphene nanoplatelets on the characteristics of polypropylene nanocomposites," Polymer Engineering \& Science, vol. 59, no. 4, pp. 752-756, 2019.

[86] S. A. Bansal, A. P. Singh, and S. Kumar, "Synergistic effect of graphene and carbon nanotubes on mechanical and thermal performance of polystyrene," Materials Research Express, vol. 5, no. 7, Article ID 075602, 2018.

[87] C. Luo, C. Shi, C. Yu, Q. Fu, and C. Pan, "Functionalized graphene for mechanical property enhancement of polymer composites," Journal of Nanoscience and Nanotechnology, vol. 18, no. 10, pp. 7203-7206, 2018.

[88] F. E. Alam, W. Dai, M. Yang et al., "In situ formation of a cellular graphene framework in thermoplastic composites leading to superior thermal conductivity," Journal of $M a$ terials Chemistry A, vol. 5, no. 13, pp. 6164-6169, 2017.

[89] W. Liu, N. Song, Y. Wu, Y. Gai, and Y. Zhao, "Preparation of layer-aligned graphene composite film with enhanced thermal conductivity," Vacuum, vol. 138, pp. 39-47, 2017.

[90] J. Tong, H.-X. Huang, and M. Wu, "Simultaneously facilitating dispersion and thermal reduction of graphene oxide to enhance thermal conductivity of poly(vinylidene fluoride)/graphene nanocomposites by water in continuous extrusion," Chemical Engineering Journal, vol. 348, pp. 693-703, 2018.

[91] S. K. Shahenoor Basha, K. Vijay Kumar, G. Sunita Sundari, and M. C. Rao, "Structural and electrical properties of graphene oxide-doped PVA/PVP blend nanocomposite polymer films," Advances in Materials Science and Engineering, vol. 2018, Article ID 4372365, 11 pages, 2018.

[92] P. Kumar, S. Yu, F. Shahzad, S. M. Hong, Y.-H. Kim, and C. M. Koo, "Ultrahigh electrically and thermally conductive self-aligned graphene/polymer composites using large-area reduced graphene oxides," Carbon, vol. 101, pp. 120-128, 2016.

[93] J.-J. Chen, Y. Li, X.-M. Zheng, F.-A. He, and K.-H. Lam, "Enhancement in electroactive crystalline phase and dielectric performance of novel PEG-graphene/PVDF composites," Applied Surface Science, vol. 448, pp. 320-330, 2018.

[94] J. Y. Wu, Y. C. Lai, C. L. Chang et al., "Facile and green synthesis of graphene-based conductive adhesives via liquid exfoliation process," Nanomaterials, vol. 9, no. 1, p. 38, 2019.
[95] J.-H. Chang, "Comparative analysis of properties of PVA composites with various nanofillers: pristine clay, organoclay, and functionalized graphene," Nanomaterials, vol. 9, no. 3, p. 323, 2019.

[96] S. H. Kim, K. Kim, and O. O. Park, "Poly(propylene)-grafted thermally reduced graphene oxide and its compatibilization effect on poly(propylene)-graphene nanocomposites," RSC Advances, vol. 6, no. 91, pp. 87828-87835, 2016.

[97] S. Suñer, N. Gowland, R. Craven, R. Joffe, N. Emami, and J. L. Tipper, "Ultrahigh molecular weight polyethylene/ graphene oxide nanocomposites: wear characterization and biological response to wear particles," Journal of Biomedical Materials Research Part B: Applied Biomaterials, vol. 106, no. 1, pp. 183-190, 2018.

[98] S. A. Bhusari, V. Sharma, S. Bose, and B. Basu, "HDPE/ UHMWPE hybrid nanocomposites with surface functionalized graphene oxide towards improved strength and cytocompatibility," Journal of the Royal Society Interface, vol. 16, Article ID 20180273, 2019.

[99] Y. Ma, D. Bai, X. Hu et al., "Robust and antibacterial polymer/mechanically exfoliated graphene nanocomposite fibers for biomedical applications," ACS Applied Materials \& Interfaces, vol. 10, no. 3, pp. 3002-3010, 2018.

[100] M. Triantou, N. Todorova, T. Giannakopoulou, T. Vaimakis, and C. Trapalis, "Physical properties of photo-aged graphene/polypropylene nanocomposites," Journal of Nanoscience and Nanotechnology, vol. 18, no. 7, pp. 5033-5041, 2018.

[101] J. Tian, J. Wei, H. Zhang, Z. Kong, Y. Zhu, and Z. Qin, "Graphene oxide-functionalized dual-scale channels architecture for high-throughput removal of organic pollutants from water," Chemical Engineering Journal, vol. 359, pp. 852-862, 2019.

[102] W. H. Chen, P. J. Liu, L. Z. Min et al., "Non-covalently functionalized graphene oxide-based coating to enhance thermal stability and flame retardancy of PVA film," NanoMicro Letters, vol. 10, no. 3, pp. 11-23, 2018.

[103] M. Ma, Z. Zhu, B. Wu, S. Chen, Y. Shi, and X. Wang, "Preparation of highly conductive composites with segregated structure based on polyamide- 6 and reduced graphene oxide," Materials Letters, vol. 190, pp. 71-74, 2017.

[104] M. Xiang, C. Li, and L. Ye, "Reactive melt processing of polyamide 6/reduced graphene oxide nano-composites and its electrically conductive behavior," Journal of Industrial and Engineering Chemistry, vol. 62, pp. 84-95, 2018.

[105] J. Shi, W. Wu, Y. Xia, Z. Li, and W. Li, "Confined interfacial polymerization of polyamide-graphene oxide composite membranes for water desalination," Desalination, vol. 441, pp. 77-86, 2018.

[106] G. S. Lai, W. J. Lau, P. S. Goh et al., "Tailor-made thin film nanocomposite membrane incorporated with graphene oxide using novel interfacial polymerization technique for enhanced water separation," Chemical Engineering Journal, vol. 344, pp. 524-534, 2018.

[107] F. Yin, J. Yang, H. Peng, and W. Yuan, "Flexible and highly sensitive artificial electronic skin based on graphene/polyamide interlocking fabric," Journal of Materials Chemistry C, vol. 6, no. 25, pp. 6840-6846, 2018.

[108] D. Wang, D. Li, M. Zhao, Y. Xu, and Q. Wei, "Multifunctional wearable smart device based on conductive reduced graphene oxide/polyester fabric," Applied Surface Science, vol. 454, pp. 218-226, 2018.

[109] C. U. Seo, Y. Yoon, D. H. Kim et al., "Fabrication of polyaniline-carbon nano composite for application in sensitive 
flexible acid sensor," Journal of Industrial and Engineering Chemistry, vol. 64, pp. 97-101, 2018.

[110] L. Xing, Y. Wang, S. Wang et al., "Effects of modified graphene oxide on thermal and crystallization properties of PET," Polymers, vol. 10, no. 6, p. 613, 2018.

[111] Y. Qi, W. Wu, X. Liu, H. Qu, and J. Xu, "Preparation and characterization of aluminum hypophosphite/reduced graphene oxide hybrid material as a flame retardant additive for PBT," Fire and Materials, vol. 41, no. 3, pp. 195-208, 2017.

[112] N. Bagotia, V. Choudhary, and D. K. Sharma, "Superior electrical, mechanical and electromagnetic interference shielding properties of polycarbonate/ethylene-methyl acrylate-in situ reduced graphene oxide nanocomposites," Journal of Materials Science, vol. 53, no. 23, pp. 16047-16061, 2018.

[113] Y. Wang, B. Wang, J. Wang et al., "Superhydrophobic and superoleophilic porous reduced graphene oxide/polycarbonate monoliths for high-efficiency oil/water separation," Journal of Hazardous Materials, vol. 344, pp. 849-856, 2018.

[114] P. R. Leeladhar and J. P. Singh, "Sunlight-driven eco-friendly smart curtain based on infrared responsive graphene oxidepolymer photoactuators," Scientific Reports, vol. 8, no. 1, p. 3687, 2018.

[115] S. Wang, X. He, Q. Chen et al., "Graphene-coated copper calcium titanate to improve dielectric performance of PPObased composite," Materials Letters, vol. 233, pp. 355-358, 2018.

[116] R. Rea, S. Ligi, M. Christian, V. Morandi, M. Giacinti Baschetti, and M. De Angelis, "Permeability and selectivity of $\mathrm{PPO} /$ graphene composites as mixed matrix membranes for $\mathrm{CO}_{2}$ capture and gas separation," Polymers, vol. 10, no. 2, p. 129, 2018.

[117] A. Mohammadi, M. Barikani, A. H. Doctorsafaei, A. P. Isfahani, E. Shams, and B. Ghalei, "Aqueous dispersion of polyurethane nanocomposites based on calix[4]arenes modified graphene oxide nanosheets: preparation, characterization, and anti-corrosion properties," Chemical Engineering Journal, vol. 349, pp. 466-480, 2018.

[118] T. Wan and D. Chen, "Mechanical enhancement of selfhealing waterborne polyurethane by graphene oxide," Progress in Organic Coatings, vol. 121, pp. 73-79, 2018.

[119] Y. Zhou, H. Lu, J. Wang, J. Zhou, X. Leng, and G. Liu, "Catalytic performance of quinone and graphene-modified polyurethane foam on the decolorization of azo dye Acid Red 18 by Shewanella sp. RQs-106," Journal of Hazardous Materials, vol. 356, pp. 82-90, 2018.

[120] C. Xia, Y. Li, T. Fei, and W. Gong, "Facile one-pot synthesis of superhydrophobic reduced graphene oxide-coated polyurethane sponge at the presence of ethanol for oil-water separation," Chemical Engineering Journal, vol. 345, pp. 648-658, 2018.

[121] E. J. You, C.-S. Ha, G.-H. Kim, and W.-K. Lee, "Poly(3hydroxybutyrate-co-3-hydroxyvalerate)/graphene oxide nanocomposite films: thermomechanical properties, oxygen transmission rates, and hydrolytic degradation," Journal of Environmental Science International, vol. 26, no. 1, pp. 1-10, 2017.

[122] R. Zine and M. Sinha, "Nanofibrous poly(3-hydroxybutyrate-co-3-hydroxyvalerate)/collagen/graphene oxide scaffolds for wound coverage," Materials Science and Engineering: $C$, vol. 80, pp. 129-134, 2017.

[123] J. Ambrosio-Martin, G. Gorrasi, A. Lopez-Rubio et al., "On the use of ball milling to develop poly(3-hydroxybutyrateco-3-hydroxyvalerate)-graphene nanocomposites (II)- mechanical, barrier, and electrical properties," Journal of Applied Polymer Science, vol. 132, no. 29, Article ID 42217, 2015.

[124] X. Shi, X. Peng, J. Zhu, G. Lin, and T. Kuang, "Synthesis of DOPO-HQ-functionalized graphene oxide as a novel and efficient flame retardant and its application on polylactic acid: thermal property, flame retardancy, and mechanical performance," Journal of Colloid and Interface Science, vol. 524, pp. 267-278, 2018.

[125] Y. Kang, C. Wang, X. Shi, G. Zhang, P. Chen, and J. Wang, "Crystallization, rheology behavior, and antibacterial application of graphene oxide- graft -poly (L-lactide)/poly (Llactide) nanocomposites," Applied Surface Science, vol. 451, pp. 315-324, 2018.

[126] X. Dai, X. Li, M. Zhang, J. Xie, and X. Wang, "Zeolitic imidazole framework/graphene oxide hybrid functionalized poly(lactic acid) electrospun membranes: a promising environmentally friendly water treatment material," ACS Omega, vol. 3, no. 6, pp. 6860-6866, 2018.

[127] M. Sajid, J. Z. Gul, S. W. Kim, H. B. Kim, K. H. Na, and K. H. Choi, "Development of 3D-printed embedded temperature sensor for both terrestrial and aquatic environmental monitoring robots," $3 D$ Printing and Additive Manufacturing, vol. 5, no. 2, pp. 160-169, 2018.

[128] S. Montes, A. Etxeberria, V. Mocholi, A. Rekondo, H. Grande, and J. Labidi, "Effect of combining cellulose nanocrystals and graphene nanoplatelets on the properties of poly(lactic acid) based films," Express Polymer Letters, vol. 12, no. 6, pp. 543-555, 2018.

[129] A. S. Z. Abidin, K. Yusoh, S. S. Jamari et al., "Surface functionalization of graphene oxide with octadecylamine for improved thermal and mechanical properties in polybutylene succinate nanocomposite," Polymer Bulletin, vol. 75, no. 8, pp. 3499-3522, 2017.

[130] P.-G. Ren, X.-H. Liu, F. Ren, G.-J. Zhong, X. Ji, and L. Xu, "Biodegradable graphene oxide nanosheets/poly-(butylene adipate-co-terephthalate) nanocomposite film with enhanced gas and water vapor barrier properties," Polymer Testing, vol. 58, pp. 173-180, 2017.

[131] S. Kashi, R. K. Gupta, T. Baum, N. Kao, and S. N. Bhattacharya, "Dielectric properties and electromagnetic interference shielding effectiveness of graphene-based biodegradable nanocomposites," Materials \& Design, vol. 109, pp. 68-78, 2016.

[132] H. Seonwoo, K.-J. Jang, D. Lee et al., "Neurogenic differentiation of human dental pulp stem cells on graphenepolycaprolactone hybrid nanofibers," Nanomaterials, vol. 8, no. 7, p. 554, 2018.

[133] Y. Wang, T. Li, P. Ma et al., "Graphene-assisted fabrication of poly( $\varepsilon$-caprolactone)-based nanocomposites with high mechanical properties and self-healing functionality," New Journal of Chemistry, vol. 42, no. 12, pp. 10348-10356, 2018.

[134] G. F. Caetano, W. Wang, W.-H. Chiang et al., “3D-Printed poly( $\varepsilon$-caprolactone)/graphene scaffolds activated with P1latex protein for bone regeneration," $3 D$ Printing and $A d-$ ditive Manufacturing, vol. 5, no. 2, pp. 127-137, 2018.

[135] W. Wang, J. R. P. Junior, P. R. L. Nalesso et al., "Engineered $3 \mathrm{D}$ printed poly( $\varepsilon$-caprolactone)/graphene scaffolds for bone tissue engineering," Materials Science and Engineering: $C$, vol. 100, pp. 759-770, 2019.

[136] S. He, N. D. Petkovich, K. Liu, Y. Qian, C. W. Macosko, and A. Stein, "Unsaturated polyester resin toughening with very low loadings of GO derivatives," Polymer, vol. 110, pp. 149-157, 2017. 
[137] G. Jiang, L. Chen, S. Jiang, K. Zhou, X. Shi, and W. Mou, "Establishment of highly effective flame-retardant unsaturated polyester resin system based on multiple strategies," Advances in Polymer Technology, vol. 37, no. 7, pp. 26742686, 2018.

[138] Y. Lv, J. Li, Z. Lei, Z. Li, X. Jing, and Y. Liu, "Situ preparation of $\mathrm{SiO}_{2}$ on graphene-assisted anti-oxidation for resol phenolic resin," Polymer Degradation and Stability, vol. 154, pp. 222-233, 2018.

[139] H. Wu, R. Yin, L. Qian, and Z. Zhang, “Three-dimensional graphene network/phenolic resin composites towards tunable and weakly negative permittivity," Materials \& Design, vol. 117, pp. 18-23, 2017.

[140] H. Zheng, Y. Shao, Y. Wang, G. Meng, and B. Liu, "Reinforcing the corrosion protection property of epoxy coating by using graphene oxide-poly(urea-formaldehyde) composites," Corrosion Science, vol. 123, pp. 267-277, 2017.

[141] S. M. Mousavi, S. A. Hashemi, M. Arjmand et al., "Octadecyl amine functionalized graphene oxide towards hydrophobic chemical resistant epoxy nanocomposites," Chemistryselect, vol. 3, no. 25, pp. 7200-7207, 2018.

[142] T. Yang, Y. Cui, Z. Li, H. Zeng, S. Luo, and W. Li, "Enhancement of the corrosion resistance of epoxy coating by highly stable $3,4,9$, 10-perylene tetracarboxylic acid functionalized graphene," Journal of Hazardous Materials, vol. 357, pp. 475-482, 2018.

[143] Q. Zhang, Y. C. Wang, C. G. Bailey et al., "Quantifying effects of graphene nanoplatelets on slowing down combustion of epoxy composites," Composites Part B: Engineering, vol. 146, pp. 76-87, 2018.

[144] G. B. Olowojoba, S. Kopsidas, S. Eslava et al., "A facile way to produce epoxy nanocomposites having excellent thermal conductivity with low contents of reduced graphene oxide," Journal of Materials Science, vol. 52, no. 12, pp. 7323-7344, 2017. 